\title{
Effects of Exchange Rate Volatility on Economic Growth: Evidence from West African Monetary Zone WAMZ Countries
}

\author{
Pabai Fofanah \\ Central University of Finance and Economics, Beijing, China
}

\begin{abstract}
:
This study examined the effects of exchange rate volatility on economic growth in four WAMZ countries. The study uses the pooled ordinary least squares, fixed effects and random effects models, and obtains a robust standard error estimate of the model by applying xtreg, cluster()fe. The empirical analysis shows that the effect of exchange rate volatility on economic growth is insignificant. Also, the results show a positive correlation between exports and economic growth. This fact implies that policies aimed at increasing exports through an appropriate exchange rate may be beneficial to the countries. In addition, the analysis also shows a positive and significant link between imports and growth rates. Therefore, this confirms that the countries actually benefit from imports resulting from the competitive pressure generated by the import of consumer goods and professional knowledge, and also from the transfer of technology embodied in the import of goods by producers. Hence, the policy of removing import barriers will benefit the countries. Furthermore, the results show that there is a positive correlation between the nominal exchange rate and economic growth rate. Thus, this shows that the nominal exchange rate depreciation policy can play an important role in improving the growth of the countries. However, the research results show that there is an inverse relationship between the real exchange rate and growth. Considering the importance of the real exchange rate, this finding suggests the introduction of a common currency in the WAMZ economies to reduce the negative effects on growth. Prudent exchange rate via monetary policy can be developed and implemented to promote growth.
\end{abstract}

Keywords: Exchange rate volatility; gross domestic product; pooled effects; random effects; fixed effects; real exchange rate.

\section{Introduction}

This article focuses on the impact of exchange rate volatility ${ }^{1}$ on the economic growth (GDP) of certain countries (The Gambia, Ghana, Nigeria, and Sierra Leone) in the West African Monetary Zone WAMZ2. Evidence has shown that from 1992 to 2017, the WAMZ countries under consideration have experienced a considerable level of exchange rate volatility. If the exchange rate is likely to spread within a larger value range in a short period of time, it means that the volatility is great. If the exchange rate fluctuates very little and tends to be stable, it means that volatility is low (see Figure 1 below).

\footnotetext{
1.Exchange rate volatility or "changes", "depreciation/appreciation", "uncertainty", "fluctuation" and "variation", denotes the amount of uncertainty or risk about the size of changes in the exchange rate.

2.The purpose of the West African Monetary Zone (WAMZ) countries is to achieve economic integration of mainly six English speaking countries (The Gambia, Ghana, Guinea, Liberia, Nigeria, and Sierra Leone) in the Economic Community of West African States ECOWAS, which plan to work towards adopting their own common currency, the Eco. (The ECOWAS is a regional political and economic alliance of 15 countries in West Africa).
} 

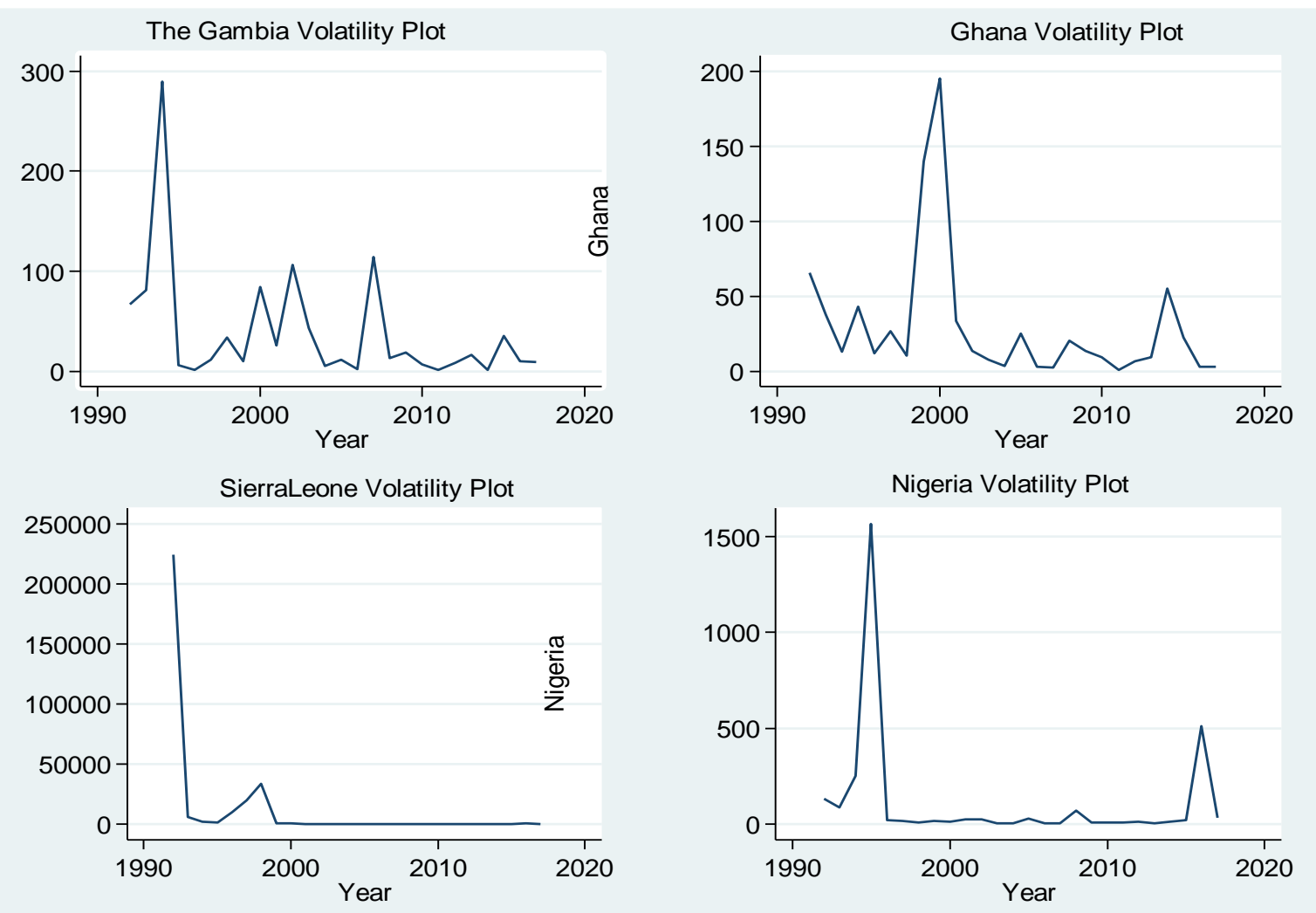

Source: Adopted from (Fofanah 2020b)

Volatility in the exchange rate has a large influence on exports, imports, trade balance, inflation rates and investment. These variables have a large impact on a country's GDP. The conventional wisdom is that exchange rate volatility maximizes transaction costs and reduces the prospects of economic growth. Given the risks of economic transactions, policy makers and academics have put great concern on the exchange rate, particularly after the collapse of the Bretton Woods system of the fixed exchange rate from 1971 to 1973 (Fofanah 2020b). Since then, the exchange rate uncertainty and its effects have become an important issue in developing countries (Umaru et al., 2018). This argument was already obvious when the West African Monetary Zone was established. One of its goals is to achieve economic integration of the six major English-speaking countries to ensure exchange rate stability and thereby promote economic growth. The latter statement is consistent with the views of Inam and Umobong (2015), who believe that exchange rate stability is essential to achieving macroeconomic stability and economic performance of any country in the global economy. By the same token, Bahmani-Oskooee and Gelan (2018) mentioned that in the case of African countries that in recent years have shown a sign of hope in their growth policies to transform their economies into sustainable development, the volatility of nominal and real exchange rate problems could be a more worrying issue in achieving their objectives. Rodrik, (2008); and Habib, et al. (2016) concluded that exchange rate is crucial to the economic growth of developing economies. On a similar note, BahmaniOskooee and Gelan (2018), posit that the instability of the exchange rate may ignite uncertainty among profit maximizing traders and reduce the level of their engagement in export and import sectors, thus leading to a diminished volume of trade and weakened economic growth. Correspondingly, Chang (2011) stated that short-term exchange rate fluctuations may also have a negative impact on the microeconomic level. Hence, exchange-rate fluctuation is usually treated as a risk. A higher risk will lead to a higher cost for risk-averse investors, which then result in less job creation. Consequently, fluctuations will induce more uncertainties and transaction costs that will result to a reduction in investment and hence low growth. The simply mentioned statements of Bahmani-Oskooee and Gelan (2018); and Chang (2011) concurs with the real 
option effect, which predicts that during high uncertainty periods, the option value of delaying investment is greater, and thus, firms may prefer to wait for the uncertainty to subside. This fact has been confirmed by Belke and Gros, (2001); Serven (2003); and Pradhan et al. (2004). See Dhakal et al. (2010) for related confirmation.

Several reasons why exchange rate fluctuations have a significant negative impact on emerging or developing economies include: Since the emerging market economy's exports generally have higher primary commodity content, exchange rate volatility should have a significant impact on foreign trade of these countries. Capital markets in emerging markets are not yet complete (see Beck et al. 2009). If the liquidity of the futures market is poor or even non-existent, these countries will not have the tools to hedge exchange rate risks. Another feature why emerging markets are on average more intolerant to large exchange rate fluctuations is due to the higher openness of these countries and heavy reliance on imports, and lower exports, which leaves them at the mercy of volatile commodity prices (see Belke and Setzer 2003; and Meniago and Eita 2017).

In the context of exchange rate wars and global imbalances, policymakers conducted in-depth discussions on the impact of the global financial crisis. The slow growth rate since the global financial crisis has prompted several countries to pursue economic policies of beggar thy neighbor ${ }^{3}$. This attempt is based on the standard Mundell-Flemming model, which predicts that currency depreciation can be extended by its expenditure conversion effects between domestic and foreign commodities ${ }^{4}$. However, contrary to traditional views, the neo-structuralist school provides a number of demand-side and supply-side channels through which depreciation/devaluation will adversely affect output. For example, when a great deal of the borrowing of firms is denominated in foreign currency and aggregate demand is constrained with agents' net worth, a real depreciation worsens balance sheets of firms, which lead to contractions in investment, output and employment. Correspondingly, in the context of the global economic slowdown and weak demand, currency devaluation does not necessarily support exports. In some cases, this policy may be counterproductive. If the competitor opposes, take a policy measure, such as depreciation (to protect exports) then such a practice may not have desirable results, especially if the country's imports are not price elastic (the imports are essential and not dependent on prices) and instead could end up hurting the trade balance through higher import prices and resulting in inflation in such economies, which then hurts the economic growth rate. Therefore, the premise that depreciation leads to export growth and trade balance improvement and subsequent improvement in output has not been consistently concluded in the literature (see Fatum et al. 2018; Umaru et al. 2018).

The relationship between exchange rate changes and economic growth remains a problem, most researchers have shown controversial results of mixed, negative, positive and insignificant effects. Some of the studies that came up with mixed conclusions include: Sani et al. (2016), Eichengreen (2008), Sibanda et al. (2013), Tarawalie et al. (2012), Aghion et al. (2006), Javed and Farook (2009), Adeolu and Godwin (2013), and Jibrin et al. (2017). Other people who find a positive relationship include: Roderik (2008), Attah-obeng (2013), Tarawalie (2010), Levy-yeyati et al. (2013), Gala (2008), Hausman et al. (2004), Di Nino (2011), Ullah et al. (2017), and Mamun et al. (2013). The negative conclusions are: Balima et al. (2018), Hua (2012), Umaru et al. (2018), Ghura and Grennes (1993), Vieira et al. (2013), Ndambendia and Alhayka (2011), Schnabl (2007), Janus and Riera-Crichton (2015), and Barguellil Ben-Salah and Zmami (2018). Some studies that have found insignificant relationships include: Inam and Umobong (2015), and Nouira and Sekkat (2012).

\footnotetext{
${ }^{3}$ Beggar thy neighbor policy refers to a policy that aims at addressing a country's domestic problems at the expense of others, through devaluation/depreciation of its domestic currency, which subsequently strengthening the dollar and prop up exports.

4.Provided the Marshall-Lerner conditions are satisfied.
} 
On balance, empirical evidence on exchange rate volatility and economic growth appears mixed at best, suggesting further investigations to better understand the relationship (see Clark et al., 2004). At the same time, extant literature seems to have largely ignored the case of WAMZ countries, open, vulnerable, growth and poverty challenged economies. The financial sectors of these economies are also small, bankcentric and not very well developed; in fact, financial development has been relatively slow and mostly inadequate (Beck et al. 2009). Given their relatively small share of world trade, WAMZ countries are price takers, making them vulnerable to external shocks. Moreover, since their trade sector comprises a large proportion of domestic economy, shocks from the world economy can have a large impact on these countries. Terms of trade shocks, for example, are a major contributor to high GDP fluctuations in these countries. For example, from 1992 to 2017, WAMZ countries under consideration show a considerable level of GDP fluctuations with all the countries under consideration showing a negative growth rate (see Figure 2).

\section{Figure 2: Country-Specific GDP Plot}
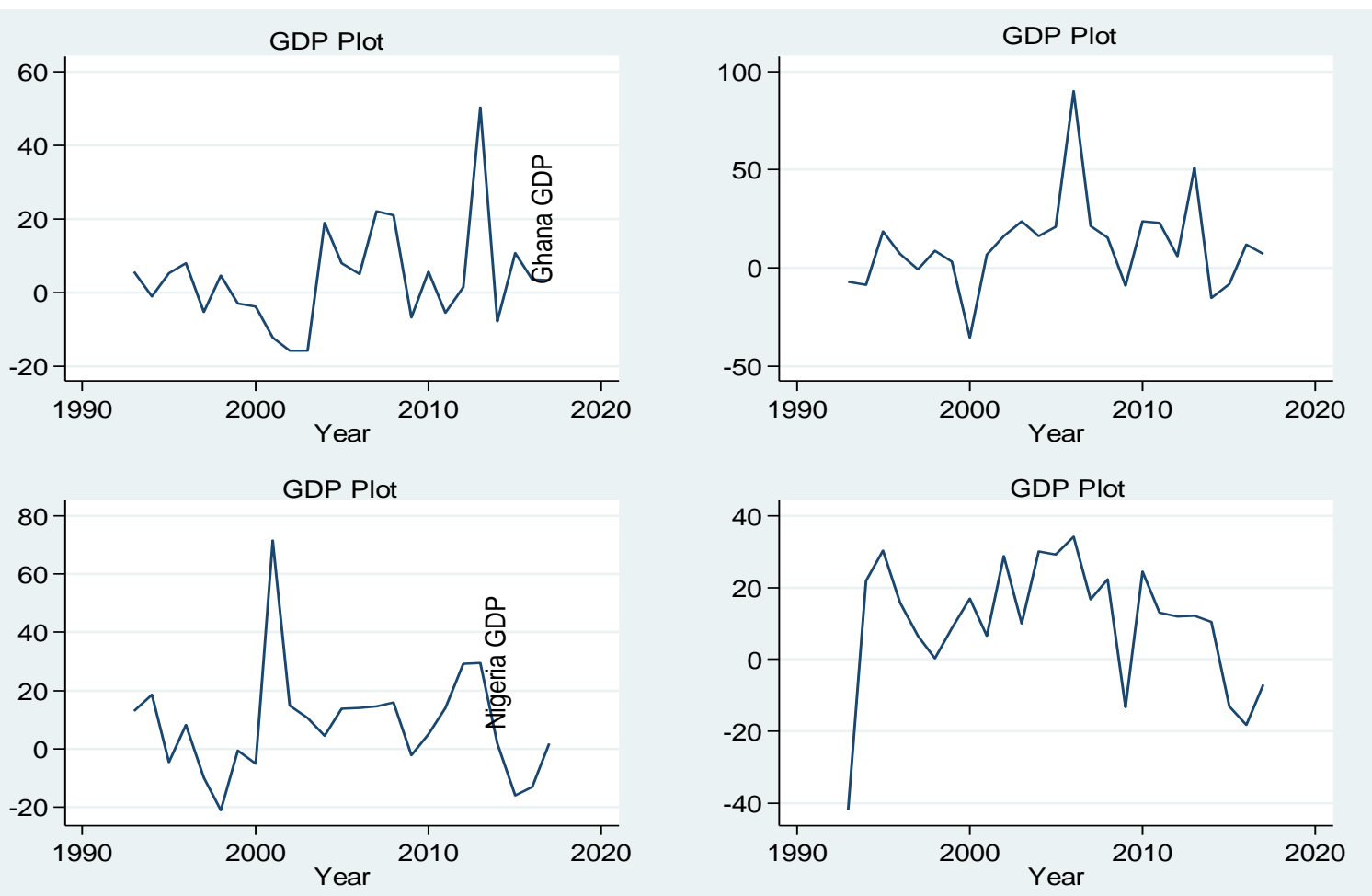

Author's plot

A critical study on the main difference in the empirical literature (see section 2) shows that most of the conclusions were due to the kind of data used in the empirical analysis, the estimation technique or methodology, the geographical region or the country where the study takes place and the proxy for volatility.

It is also found that although these studies also focus on the impact of exchange rate fluctuations on economic growth, there seem to be a few studies specifically aimed at WAMZ countries. Some researchers have studied the relationship between exchange rates and economic growth from the perspective of individual country analysis and using time series data analysis. In contrast, recent studies, which employed the panel based approaches are more desirable because heterogeneity issues can be modelled by including country-pair "individual" effects, and thus tend to find more robust results (for example see, Dell'ariccia 1999; Clark et al. 2004). Analyzing the impact of exchange rate fluctuations on economic growth in the panel data environment has obvious advantages. By combining cross-sectional and time-series dimensions, a 
panel data analysis can control not only for temporal effects but also heterogeneity across the countries. Panel data usually contain more degrees of freedom and less multicollinearity than cross-sectional or time series data because of a large number of observations. It has the advantage of distinguishing between fixed effects and random effects, so it improves the efficiency of econometric estimation. Furthermore, it allows the researcher to control the effect of missing variables and permits accurate predictions for individual outcomes by pooling the data rather than generating predictions of individual outcomes; thereby making it appropriate to apply panel data analysis for WAMZ countries in this study. Hence, it is necessary to conduct a research in the WAMZ countries under consideration (The Gambia, Ghana, Sierra Leone, and Nigeria) to understand the impact of exchange rate fluctuations on economic growth. In this regard, the research question is as follows: What is the impact of exchange rate volatility on the economic growth of the WAMZ countries under consideration? Thus, the research goal has been developed based on the research question. The goal is: To investigate the impact of exchange rate volatility on economic growth of the WAMZ countries under consideration; and to recommend policies based on the outcome of the theoretical and empirical analysis. Hence, the focus of this paper will be to solve the above research problem and overcome the shortcomings and limitations of previous studies.

A study of this nature is significant for WAMZ countries because a recent publication by the African Development Bank (2019), remarked that "West African countries tend to export mainly primary commodities whose prices are exogenously determined, and import manufactured products." Hence, the relative price of the commodity is crucial in determining the economic growth rate of these countries. Therefore, understanding the impact of exchange rate fluctuations on economic growth has become an important issue in formulating the best exchange rate policy for WAMZ countries.

Second, the countries under consideration are working hard to achieve economic integration, and they plan to work hard to adopt their own common currency the Eco. Various options to strengthen currency integration, including proposals for the eventual formation of a currency union in WAMZ countries, are now an active area of research and policy debate. As these countries are striving to strengthen their regional integration and set up a common currency union, understanding the direction and extent of the impact of exchange rate fluctuations on their economic growth prospects has become an important issue. If exchange rate fluctuations between these countries have a negative impact on their economic growth, the attempt to introduce a common currency will reduce the negative impact of exchange rate fluctuations on the economic growth of these countries. As such, it will enhance cross border trade, countries across the region and even beyond will be able to move and spend money across different countries in the region without worrying about exchange rate costs and this event will improve trade by allowing specialization, which subsequently enhances economic growth. Hence, the results of this paper should especially provide information for the plans being implemented, which will be important information for WAMZ countries that are moving to a common currency union.

Furthermore, the almost complete neglect of imports, exports, trade balance, inflation, nominal, and real exchange rate in the growth prospect of WAMZ countries is still rather surprising since economic intuition and theory suggest that these variables may serve an important channel to either increase or decrease GDP growth. Such neglect is unfortunate because it helps to reinforce the deep-seated WAMZ countries' research bias against the impact of these variables on economic growth in WAMZ countries. Therefore, this study will attempt to promote a more balanced and comprehensive approach to the analysis of the variables and economic growth in WAMZ countries, which in turn will help to better understand the potential contribution of the variables to the zone's growth and development.

In terms of scope and methodology, this paper has contributed to the previous literature in a very important way. The study is among the few to research on the impact of exchange rate fluctuations on the economic growth of certain WAMZ economies through a panel data set. 
The rest of the study is as follows; Section 2 presents the literature, theoretical and empirical review of past works by different writers on the exchange rate, economic growth, and the related field of study. Section 3 describes the model specifications, the definition of variables, the scope and source of the data, the measurement of exchange rate volatility and methodology. Section 4 provides a summary of the results and interpretation. Section 5 presents conclusions and policy recommendations.

\section{Theoretical and the empirical literature}

\section{1: The theoretical literature}

Economists normally agree that changes in the exchange rate can either be nominal or real (see Betten and Belongia 1984). The nominal exchange rate is the relative price of the currencies of two countries (Fofanah 2020a). These rates are observable and are a result of the market and other forces out of our control (Kristinek and Anderson, 2002). The real exchange rate involves adjusting to a specify nominal exchange rate for relative inflation between a domestic economy, and the rest of the world to determine the effect on incentives to produce, purchase and store commodities and services (Snape 1988; Kristinek and Anderson, 2002). Fofanah (2020a) opined that the concept is a measure of the degree of competitiveness of a country in the international market. Expressed as RER $=\mathrm{e}^{*} \mathrm{P}_{\mathrm{f}} / \mathrm{P}_{\mathrm{d}}$.

Where: RER = real exchange rate

$\mathrm{e}=$ nominal exchange rate

$\mathrm{P}_{\mathrm{f}}=$ foreign price level

$\mathrm{P}_{\mathrm{d}}=$ domestic price level

One of the problems affecting consumers and the world economy is the exchange rate fluctuations. Exchange rate fluctuations can create inefficiency and distort world prices. Moreover, the long term profitability of investment, export opportunities and price competitiveness imports are all impacted by longterm movement exchange rates. Hence, international investors/companies usually have to pay very close attention to countries' exchange rate movement. Theoretically, when the exchange rate appreciates, foreign goods become cheaper in the domestic market and there is downward pressure on domestic prices. In contrast, the prices of domestic goods paid by foreigners go up, which tends to decrease foreign demand for domestic products (Fofanah, 2020a). Thus, the exchange rate appreciation tends to reduce exports, and if there is no corresponding change in the relative prices in the rest of the world, the appreciation of the exchange rate would represent a decrease of the country's competitiveness in the international market (Tarawalie et al. 2012; Jiang 2014). The reduction in competitiveness may negatively impact on the trade balance, which might subsequently reduce the GDP growth rate.

Furthermore, an appreciated domestic currency can spell trouble for the domestic companies that export a lot of goods to foreign countries. Since their products are priced in domestic currency, those exports become more expensive for the foreign consumers and businesses that have to pay for them in domestic currency. The value of the profits they make on export sales falls, as well, when they convert overseas profits back to domestic currency. The fall in the value of export sales might hinder production expansion and hence further investment, which tends to affect the GDP growth rate. Correspondingly, the appreciation of the local currency will harm domestic companies. That's because when the domestic currency appreciates, domestic consumers are able to buy imported goods for fewer dollars, making domestic-made products more costly in comparison. However, if the domestic currency appreciates, and the cost of imported materials drops, domestic producers that hold their prices steady will see their margins increase. Alternatively, they have the option of dropping their prices to grab a bigger chunk of the market, without surrendering any of their profits. Moves like this can compensate for the loss of price competitiveness due to an appreciation of the domestic currency both at home and abroad. 
Exchange rate depreciation has the opposite effect. It tends to improve the competitiveness of domestic goods in foreign markets while making foreign goods less competitive in the domestic market by becoming more expensive, this event transmits to higher exports and lower imports (Tarawalie et al., 2012). If the domestic currency depreciates, exports become cheaper due to the change in relative prices. While it will appear that domestic businesses benefit when the domestic currency depreciates, reality is not so simple. When the domestic currency depreciates in value compared to other foreign currencies, the price of imported raw materials increases, and products that are manufactured in the domestic economy can cost more to make. As such, producers may reduce the volume of production because of the relatively high cost of imported inputs, which might also harm GDP growth rate.

\section{Impact of exchange rate movement on economic growth}

According to the standard Mundell-Fleming model (Mundell 1963; Fleming 1962), under a flexible exchange rate system, fiscal policy does not affect output, while monetary policy is very effective in affecting output (under the assumption that international capital market is integrated). Since the increase in money supply (or a decline in demand for money) is associated with a decrease in interest rate, this policy tends to discourage profit seeking domestic investors, which leads to an outflow of financial capital as domestic investors seek higher returns by purchasing foreign bonds elsewhere. Investors need to buy foreign currency to acquire foreign bonds. Hence, the supply of domestic currency increases to buy the foreign currency needed to acquire foreign bonds. The domestic exchange rate depreciates. This event makes domestic goods become cheaper and more competitive in the international market compared to foreign goods, thereby shifting world demand on to domestic goods, thus improving the trade balance and thereby stimulating domestic output, and the domestic unemployment rate falls below its normal (full employment) level. This pressure on the labor market causes nominal wage and price level to rise. As the price levels rise, the real money stock will fall, and the exchange rate will reduce back to its original level (appreciate). Therefore, monetary expansion has a temporary downward effect on the real exchange rate and an upward effect on real income or output. The analysis presumes that the short run adjustment of output and employment is immediate, but it takes time for a devaluation to increase domestic demand and subsequently increase output. This event has implication for exchange rate adjustment.

In the case of fiscal expansion, the initial increase in domestic government spending will lead to excessive demand for goods and tend to increase output, employment and income. This in turn increased the demand for money and the level of interest rates. The fact that the domestic interest rate is now higher than the world interest rate causes an inflow of capital, which causes an appreciation of the domestic exchange rate. Therefore, in this case, domestic goods are more expensive than foreign goods, their competitiveness is weaker, and the trade balance deteriorates, thereby depressing domestic output, employment and income. A new equilibrium is reached in which the trade balance is worsened while output and the interest rate are restored to their original levels. However, as many well-known economists have observed, the MundellFleming model is static and thus cannot solve problems related to long-term and transitional dynamics of private wealth and government financing. In order to address this limitation, in his paper "Expectations and Exchange rate Dynamics", Dornbusch (1976) introduced a more sophisticated, "rational" private agents' expectation into the model.

This extension implies an "overshooting" result, since volatility or adjutment is more fundamental to the market than speculation and inefficiencies in the foreign exchange market. More basically,

\footnotetext{
5 The overshooting model establishes a relationship between sticky prices and volatile exchange rates; it happens because of "difference of speed of adjustment across markets." It believes that foreign exchange rates will temporarily overreact to changes in monetary policy to compensate for the sticky prices of commodities in the economy. This means that in the short run, the equilibrium level will be reached through shifts in financial market prices, so, the foreign exchange market,
} 
Dornbusch submits that in the short-run, equilibrium is reached in the financial markets, and in the long run, the price of goods responds to changes in the financial markets: in the short run, following a monetary expansion, the exchange rate depreciates immediately, this accounts for a fluctuation in the exchange rate and terms of trade; During the adjustment process, the rise in price may be accompanied by an appreciation of the exchange rate, so that the trend behavior of the exchange rate becomes a strong contrast with the cyclical behavior of exchange rate and price; And the exchange rate is observed to be a key channel in transmitting to aggregate demand for domestic output during the adjustment process - This is the direct impact of exchange rate fluctuations on domestic inflation. Thus, the intuition is that prices of goods in an economy do not immediately react to a change in foreign exchange rates. Instead, the domino effect covering other participants (including financial markets, currency markets, derivatives markets, and bond markets) helps to transfer its effects to commodity prices. Correspondingly, Driskill (1981) proposed an exchange rate determination model, which is characterized by imperfect asset substitutability between domestic and foreign bonds, sticky commodity market prices, and rational expectations. This model is used to analyze the exchange rate response to a step change in the relative money supply. The assumption of imperfect asset substitution allows analysis to be introduced into trade flows that respond to changes in relative prices. These flows produce non-monotonic exchange rate adjustments to the long-term equilibrium. These non-monotonic adjustments are consistent with rationality and may cause short-term undershoot or overshoot.

The neo-structuralist school provides a number of demand-side and supply-side channels through which devaluation/depreciation will have an adverse effect on output. On the other hand, the literature also identifies three channels through which exchange rate changes affect GDP. These are aggregate demand, aggregate supply and balance sheet channels (Karadam 2014; and Tarawalie, 2010). As mentioned earlier, in the aggregate demand channel, exchange rate depreciation has increased the international competitiveness of domestic commodities, increased net exports, improved the balance of payments, and thus increased the gross domestic product. On the other hand, exchange rate appreciation reduces the international competitiveness of domestic goods, reduces net exports, worsens the balance of payments, and reduces GDP.

The aggregate supply channel posits that a devaluation/depreciation of the domestic currency would have a contraction effect on output and hence economic growth. Depreciation increases the domestic currency cost of imported inputs and reduces the volume of imported inputs. Reduction in imports implies insufficient inputs necessary for production. Thus, because of the lack of enough inputs and higher cost vis-a-vis to the prices of their domestic final products, firms tend to produce less, which leads to a reduction in aggregate supply. Also, the higher cost of imported input, which may result from a depreciation of the domestic currency, might lead to higher cost of the final products. This event will impact negatively on the real wage of workers. Where wages are flexible, the workers will agitate for higher nominal wages to protect their purchasing power. Thus, the nominal wages will adjust proportionately to the general price level. Such increase in wages increases the cost of production and could produce adverse supply effects which will impact negatively on output and hence economic growth.

Frankel (2005) point out the balance sheet effects of devaluation. Karadam (2014) also report in his thesis that, Frankel (2005) emphasizes that the balance sheet effect is the dominant reason that explains the

the money market, the derivatives market, the bond market, the stock market etc., but not through shifts in the prices of goods themselves. Gradually, then, as the price of goods unsticks, and adjusts to the reality of these financial market prices, the financial market, including the financial exchange market, adjusts to this financial reality. Therefore, initially, the foreign exchange market overreacted to changes in monetary policy, which created a balance in the short term. And, as the price of goods gradually responds to these financial market prices, the foreign exchange markets temper their reaction, and create a long-term equilibrium. Thus, there will be more volatility in the exchange rate due to overshooting and subsequent corrections that would otherwise be expected (see Chen, 2019). 
recessions following many of the 1990s devaluations. Thus, one can submit that most Sub-Saharan African countries adopted the structural adjustment program due to balance sheet problem (adverse balance of payment accounts), which led to fluctuations of their currencies (see Fofanah 2020b). For example, if a country has a large external debt position, depreciation of domestic currency may reduce the net worth of households and government and hence aggregate demand. A depreciated currency increases the domestic currency costs of servicing debt. Government can finance increased debt service payments by reducing its expenditures, increasing taxes or domestic borrowing. All these modes of financing have negative implication on aggregate demand, profit, capital stock and hence output and economic growth. The exchange rates can be fixed at a predetermined level (fixed exchange rate) or they can be flexible to reflect changes in demand (floating exchange rate). This can affect national output and hence growth either negatively or positively because exchange rates have impact on prices (see Attah-Obeng et al. 2013). Correspondingly, Tarawalie (2010) reported that some studies believe that devaluation has an expanding effect on the growth of real output. Others believe that exchange rate depreciation will have a contraction effect on actual output.

The traditional views such as the elasticity, absorption and the Keynesian approaches assert that devaluation/depreciation has a positive effect on output and hence economic growth. The elasticity approach is viewed on the basis of price elasticity of demand for imports and exports. It owes its origin from Bickerdike (See Dhakir Abbas Ali et al. 2014). It assumes that currency devaluation/depreciation is expected to lower the price of a country's exports abroad and raise the price of imports in the domestic market, thereby resulting in an increase in exports and a decrease in imports. The rise in exports subsequently leads to an increase in aggregate demand of domestically produced goods, which will subsequently lead to economic growth. The figure below shows the transmission mechanism of depreciation and appreciation on economic growth.

Figure 3: The Transmission mechanism of exchange rate depreciation and (appreciation) on economic growth.

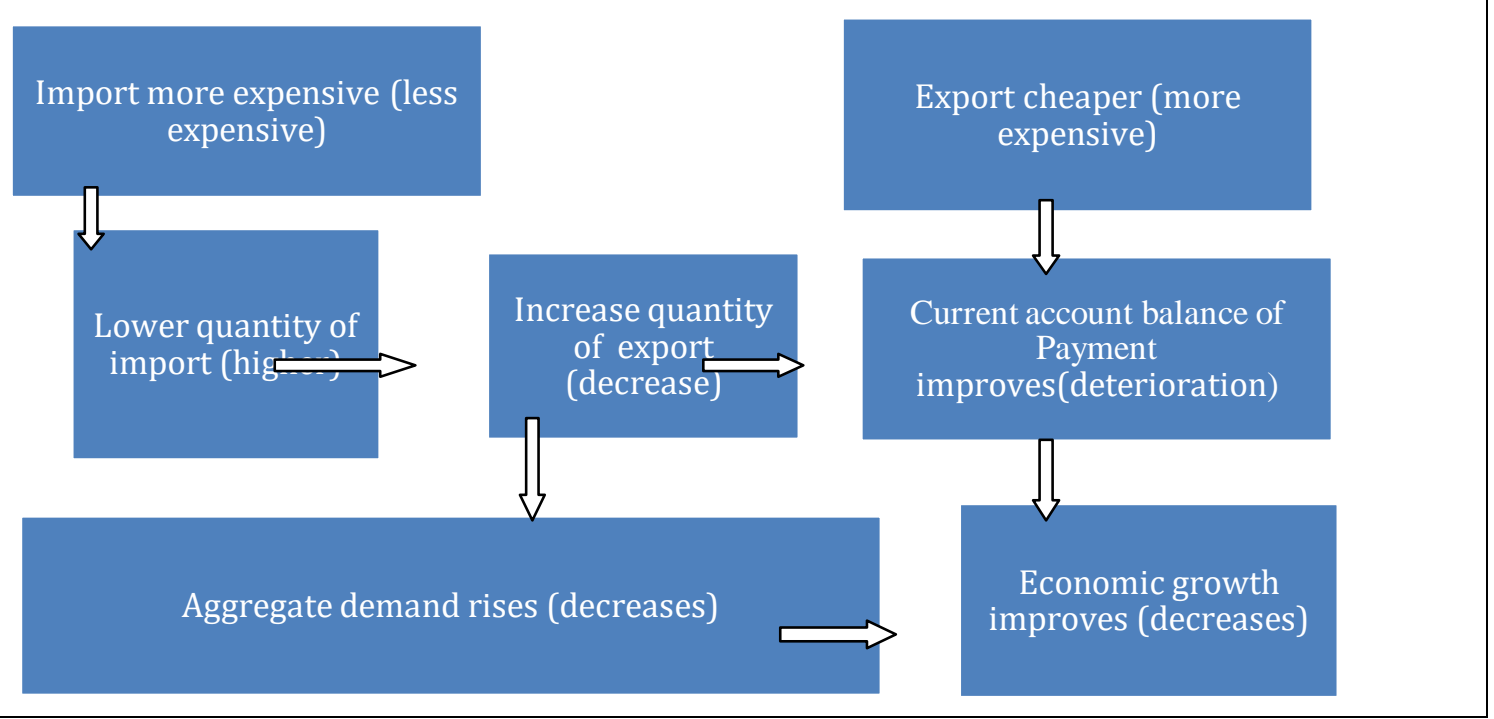

Source: By the author

As already observed, for the elasticity approach to be successful, the Marshall-Lerner condition must be satisfied. However, if the change in the relative price of exports and imports leads to very small expenditure switching, for example, if there are no domestic substitutes for imported goods as the case is in most WAMZ countries, devaluation/depreciation may worsen the deficit and thereby reduce growth. Thus, the elasticity approach therefore, considers the responsiveness of imports and exports to changes in the exchange rate. For example, if the foreign demand for exports is elastic, a devaluation or depreciation of a country's currency is 
expected to cause a large increase in export volume, while the value of export falls. On the other hand, if foreign demand for domestic exports is inelastic, the devaluation or depreciation will keep the export volume constant, while the export value will decline. In reality, however, devaluation/depreciation may take time to work since exports have inelastic supply, especially in West Africa due to external factors like unfavorable terms of trade. Foreign consumers may also take time to adjust from domestic goods to foreign exports. Thus, the Balance of Payment may actually worsen soon after devaluation, before improving at a later stage. This phenomenon is known as the J-curve effect. This is the tendency of a country's trade balance to first deteriorate before improving as a result of a devaluation/depreciation of a country's currency. Therefore, even if the Marshall-Lerner condition is met, the current account may worsen in the short-run, which will deteriorate growth, before improving in the longer term, which later improves growth.

The absorption approach states that a country's balance of trade will only improve if the country's output of goods and services increases by more than its absorption, where the term 'absorption' means expenditure by domestic residents on goods and services. This method was first proposed by Alexander (1952, 1959). The absorption approach merges the elasticity approach with the Keynesian income-expenditure identity (see Dhakir Abbas Ali et al. 2014). The absorption approach began with the assumption that domestic expenditure or absorption (A) is equal to consumption (C) plus domestic investment (I) plus government expenditure $(\mathrm{G})$ plus import $(\mathrm{M})$, all variables are expressed in real terms as an extension of the Keynesian income/output model. That is;

$\mathrm{A}=\mathrm{C}+\mathrm{I}+\mathrm{G}+\mathrm{M}$

But a nation's real income $(\mathrm{Y})$ equals its total expenditures on output. This is expressed as:

$\mathrm{Y} \equiv \mathrm{C}+\mathrm{I}+\mathrm{G}+\mathrm{X}$

Where $\mathrm{X}$, is export. Thus the current account balance becomes $(\mathrm{Y}-\mathrm{A})$, this gives:

$\mathrm{Y}-\mathrm{A}=(\mathrm{C}+\mathrm{I}+\mathrm{G}+\mathrm{X})-(\mathrm{C}+\mathrm{I}+\mathrm{G}+\mathrm{M})=\mathrm{X}-\mathrm{M}$

By letting (B) equal the trade balance $(\mathrm{X}-\mathrm{M})$ in equation (1.2) yields;

$\mathrm{Y}-\mathrm{A}=\mathrm{B}$

In other words, domestic production/income minus absorption equals the trade balance. The statement shows that policies to correct trade imbalances can be roughly divided into two categories; those that aim to increase output (maximize output), and those that aim to reduce expenditure/absorption (decrease expenditure). Thus, if the economy is operating at less than full employment, domestic currency devaluation/depreciation will increase consumption of domestic goods and assets and reduce consumption of foreign goods and assets, national income or output will increase more than the national expenditure, this event will subsequently improve the balance of payment and hence growth rate. However, if a nation is at full capacity utilization (full employment), a depreciation of domestic currency may increase consumption of domestic goods and assets and reduce consumption of foreign goods and assets, but output or real income will not rise. Thus, domestic price will begin to rise, which subsequently leads to reduction in consumption of domestic goods, thereby returning the economy to its original trade balance. Note that, full employment isn't when everyone has a job. Instead, it is when inflation starts to rise because businesses cannot find enough workers ${ }^{6}$. Since West Africa countries normally have unemployed resources, the extra output required to meet the increase supply, which is needed to reduce the inflation could be provided by the re-

${ }^{6}$ Economists technically define full employment as any time a country has a jobless rate equal or below what is known as the "non-accelerating inflation rate of unemployment." The estimate of this measure is based on the historical relationship between the unemployment rate and changes in the inflation rate. If the unemployment rate is lower than this measure, it indicates that the economy is in a state of full employment, companies cannot easily find workers, inflation and wage increases. If this is not the case, then there are too many workers to work, and the inflation rate is still low (see Zagorsky, 2018). 
absorption of these resources into employment. Under such circumstances, expenditure switching could increase employment and income, which will subsequently lead to output growth.

In short, the theoretical literature reveals some important facts about the theoretical prediction of the impact of exchange rate changes on economic growth. It raises inconsistencies and broadens our understanding of the various assumptions that each theory assumes to reach its conclusions. Furthermore, it has also emphasized the usefulness of the Mundell - Flemming model, the elasticity, absorption and Keynesian approaches in explaining the link between exchange rate changes, and economic growth. In addition, it also emphasizes the validity of the Mundell-Flemming model, elasticity, absorption, and the Keynesian approaches in explaining the link between exchange rate changes and economic growth. It has been noted that, exchange rate depreciation/devaluation will only increase exports and thereby improving growth if the Marshall-Lerner condition is met. However, in the short term, depreciation/devaluation will worsen the trade balance, which in turn worsens economic growth. But in the long run, this will improve the trade balance and thus economic growth, as shown by the J-curve phenomenon.

In general, the assumption that exchange rate changes will adversely affect economic growth depends on many specific assumptions, which may not be applicable in all situations. Hence, the ambiguities and inconsistent theoretical conclusions emphasized the importance of investigating the relationship between the exchange rate changes and economic growth empirically in the case of the WAMZ economies under consideration.

\section{2: The Empirical review}

The empirical literature on exchange rate volatility and economic growth in WAMZ economies is limited. However, the related studies on the subject are presented as follows: Tarawalie, Sissoho, Conte, and Ahortor (2012), investigate the effect of changes in the exchange rate on output growth in the WAMZ economies. They designed a general equilibrium model of an open economy and used quarterly data series (1981-2010) for all countries except Ghana and Guinea. The results show that there is a negative correlation between the real exchange rates of Liberia and Sierra Leone and real GDP growth. However, the impact of exchange rates on output in The Gambia, Ghana, Guinea, and Nigeria though positive, remained weak, which may be partly due to supply side factors as evident from their results. The paper of Umaru, Aguda, and Davies (2018) examine the effects of exchange rate volatility on economic growth of West African English speaking countries. Using panel data stream since 1980 to 2017. The results obtained showed that the real exchange rate is statistically significant and negatively related to GDP in West African English speaking countries. Sani, Hassan, and Azam (2016) conducted an empirical study on the impact of exchange rate fluctuations from 1991 to 2014 on the output levels of five English-speaking ECOWAS countries (Nigeria, Ghana, Gambia, Sierra Leone, and Liberia). Using cointegration testing and error correction models as estimation techniques, short-term and long-term relationships between variables are obtained in each country. Generally, exchange rate fluctuations have a significant impact on output at least for all countries considered in the study, with the exception of Liberia, which has a negative impact.

On the other hand, Balima, Barhoumi, Gorbanyov, Versailles and Towfighian (2018) examine the fundamentals behind West Africa Economic and Monetary Union WAEMU's recent economic growth acceleration in comparison to the group of low income developing countries (LIDCs). The baseline regression shows that the exchange rate volatility is negative and statistically significant, which indicates that the increase in the level of exchange rate volatility reduces the possibility of growth acceleration. Whereas, Jibrin, Jelilov and Gayypov (2017) empirically analyze the impact of exchange rate on gross domestic product and other macroeconomic aggregates in ECOWAS for the period 1990 to 2014. The classical linear regression model (CLRM) was used in the analysis of 10 countries, and the results showed that the exchange rate has a significant relationship with 4 of 9 countries. These countries include Benin, 
Guinea-Bissau, Liberia and Nigeria. In addition, the exchange rate is positively correlated with GDP growth, while it is negative in Ghana, Guinea-Bissau and Sierra Leone.

Ghura and Grennes (1993) used aggregated time series and cross-sectional data from 33 countries in SubSaharan Africa, their results confirmed a negative correlation between real exchange rate (RER) misalignment and economic growth. They observed that higher levels of misalignment are accompanied by higher levels of macroeconomic instability. Therefore, this means that lower RER misalignment levels can lead to better economic performance. Ndambendia and Alhayky (2011) investigate the long-run relation between effective real exchange rate volatility and economic growth in 15 Sub-Saharan African countries using panel unit root and cointegration tests over the period 1980 to 2004. Use fully modified ordinary lease square OLS (FMOLS) to estimate long-term relationships. Their result suggests that real exchange rate volatility negatively affects economic growth when the ratio of domestic credit to GDP is below the threshold value, which is 57\%. On the other hand, the empirical analysis of Adeolu and Godwin (2013) examines the effect of exchange rate volatility on the economic activities in Africa and its sub-groups during the period 1986 to 2011, using a panel data. Both the demand and supply channels are explored to trace the impact of the exchange rate volatility on price as well as aggregate demand and its components. The results reveal that exchange rate volatility produced more significant effects in the non-Communauté Financière d'Afrique ("Financial Community of Africa") CFA group than in the CFA. Abida (2011) investigates the role of real exchange rate RER misalignment on long-run growth in three countries of the Maghreb (Tunisia, Algeria and Morocco) over the period 1980 to 2008. This paper uses the fundamental equilibrium exchange rate (FEER) method (from which the misalignment is derived) and the dynamic panel growth model to estimate the equilibrium RER. The results indicate that the coefficient for RER misalignment is negative.

Other studies have studied this topic in a single country framework analysis, as follows: Inam and Umobong (2015) analyzing the relationship between exchange rate movements and economic growth in Nigeria using annual data from 1970 to 2011. The Ordinary Least Square (OLS) technique, and the Granger causality test, revealed the existence of a positive and insignificant relationship between exchange rate and economic growth in Nigeria. Their results also show that, there is no causality between exchange rate and economic growth in Nigeria. Their results show that exchange rate depreciation can reduce output, so economic growth and exchange rate appreciation can increase output and thus economic growth, but the impact is insignificant. Anyanwu, Ananwude \& Okoye (2017) ascertain the impact of real exchange rate on gross domestic product and manufacturing capacity utilization of Nigeria from 1986 to 2015. Using the ordinary least square estimation technique, the analysis reveals a long run relationship between exchange rate and economic growth. The result reveals a positive, but insignificant relationship between the real exchange rate and real gross domestic product. While the Granger causality test reveals that real exchange rate has significant impact on real gross domestic product, the real exchange rate significantly impacts manufacturing capacity. The authors recommend prudent exchange rate policies be put in place to ensure the proper determination of the value of the Naira against other currencies.

The empirical analysis of Sibanda, Ncwadi and Mlambo (2013) examines the impact of real exchange rates on economic growth in South Africa using quarterly time series data for the period of 1994 to 2010. Johansen cointegration and vector error correction model are used. The results reveal that real exchange rates have a dampening long run impact on economic growth in South Africa. It is noted from the result that, the undervaluation of the currency significantly hampers growth in the long run, whilst it significantly enhances economic growth in the short run. On the other hand, Oloyede, and Fapetu (2018) evaluate the effect of exchange rate volatility on economic growth in Nigeria from 1986 to 2014. The study determines the extent and manner to which economic growth responds to exchange rate volatility in Nigeria. Using the real effective exchange rate and employing the generalized autoregressive heteroskedasticity (GARCH) model and the generalized method of moments, the study discovers high volatility of real effective exchange 
rate. The findings also reveal that the real effective exchange rate is negatively and significantly related to economic growth. Therefore, this event shows that fluctuations are harmful to Nigeria's economic growth. The paper suggests that the government should constantly seek to maintain a stable exchange rate in Nigeria. Ullah, Khan, and Khan, Saif-ud-Din (2017) explore the relationship between exchange rate and economic growth in Pakistan for the period 1976 to 2010. Using the simultaneous equation model, and two, and threestage least squares (2SLS and 3SLS) techniques. The results show that the exchange rate has a positive effect with economic growth through the channels of export promotion incentives, enlarging the volume of investment, enhancing foreign direct investment inflow and promoting import substitute industries. In a related study, Javed and Farooq (2009) investigate the relationship between economic growth and exchange rate volatility in Pakistan for the period 1982 to 2007. Employing error correction techniques along with autoregressive distributed lag ARDL, the results of the empirical analysis suggest that exchange rate volatility has a long run positive relationship with economic growth. Whereas in the short run exchange rate volatility shows positive and negative relationships with economic growth. Thus, the result suggests that, domestic economic performance is very sensitive to exchange rate volatility in the long-run period.

Kogid et al. (2012), investigate the effects of the exchange rates on economic growth in Malaysia using time series data spanning from 1971 to 2009 . Both exchange rates, nominal and real, are considered to have similar effects on economic growth. The results of the ARDL bounds test suggest that long-run cointegration exists between nominal and real exchange rates and economic growth with a significant positive coefficient recorded for real exchange rate. In addition, the results of error correction model ECM-based ARDL also reveal that both exchange rates have a similar causal effect towards economic growth. Considering the importance of exchange rate variables, especially the real terms, these findings suggest that a systemic exchange rate via monetary policy be properly developed and implemented to promote the stability and sustainability of economic growth in Malaysia.

In the study of Hua (2012), a Cobb-Douglas production function with enhanced real exchange rate is proposed, and the GMM system estimation method and panel data of 29 provinces in China from 1987 to 2008 are used. The results show that the real exchange rate appreciation had a negative effect on economic growth, which was more marked in coastal provinces than in inland provinces, contributing to a reduction in the difference in GDP per capita between the two provinces. Razzaque et al. (2017) empirically investigate the effects of exchange rate movements on economic growth in Bangladesh. Using a suitable analytic framework to derive an empirical specification and employing cointegration techniques to determine the output response to Bangladeshi currency depreciations. The results suggest that in the long run, a depreciation of the real exchange rate is associated with a rise in aggregate output. However, a contractionary effect is observed in the short run. The results imply that long-run expansionary effect of real depreciations may be appealing for considering exchange rate policy as a development strategy.

On the other hand, Koirala (2018) empirically assesses the impact of real effective exchange rate (REER) on economic growth of Nepal. The study uses annual time series data for the period of 1975 to 2015. Engel Granger's residual test and error correction model are used to detect the impact of REER on Nepal's real GDP. The results of the study reveal that the real effective exchange rate has a positive impact on the real GDP of Nepal. Based on the findings, the study concludes that the transmission mechanism of REER through aggregate demand hold in case of Nepal and this result is compatible with the traditional approach to exchange rate. The study recommends that Nepal must use the real exchange rate as one of the macroeconomic policies to stimulate economic growth.

On the other hand, Kim et al. (2007) investigates the relationship between exports, imports, and economic growth using quarterly data from 1980 to 2003. Results show that imports have a significant positive effect on productivity growth, but exports do not. Furthermore, the evidence reveals that the productivityenhancing impact of imports is due to competitive pressures arising from consumer goods import and 
technological transfers embodied in capital goods imports from developed countries. Most of the study's results still hold using gross domestic product growth rather than productivity growth as the measure of economic growth. The evidence implies that under certain circumstances, import liberalization can make a positive and significant contribution to growth and development. Mishra (2012) investigates the dynamics of the relationship between imports and economic growth in India for the period 1970-1971 to 2009-2010. Using time series techniques such as vector error correction estimates and Granger causality tests, the results show the existence of a two-way relationship between import growth and income growth in the long run.

Combined with the analysis of different countries, other studies on this topic have also been conducted. These include; Vieira and MacDonald (2012) used time series data from 1980 to 2004 and used cointegration methods to study the effect of real exchange rate misalignment on long-term growth in 90 countries/regions. The results of the analysis suggest that a more depreciated (appreciated) real exchange rate helps (harms) long-run growth. On the other hand, the paper of Rodrik (2008) shows that undervaluation of the currency stimulates economic growth particularly for developing countries. LevyYeyati, Sturzenegger and Gluzmann (2013) examine whether "fear of appreciation" has a positive impact on growth performance in developing economies. Looking alternatively at two sample periods from 1974 to 2007 and 1993 to 2007, the finding shows that depreciated exchange rates led to higher growth. The empirical work of Eichengreen (2008) analyzes the role of real exchange rate in the growth process, using a sample of 28 industries from 40 emerging market countries with annual data covering the period 1985 to 2003. Time fixed effects are included throughout. The results suggest that depreciation, or an increase in real exchange rate fosters the growth of industry employment, but volatility appears to have a significant negative impact on employment growth. Thus, implying that volatility in exchange rate dampens economic growth.

Habib, Mileva and Stracca (2016) investigate the impact of real exchange rate movements on economic growth based on five-year average data from a panel of over 150 countries in the post Bretton Woods period. They use external instruments to deal with possible reverse causality from growth to the real exchange rate. The findings show that a real appreciation (depreciation) reduces (raises) significantly the annual real GDP growth. Karadam and Ozmen (2016) empirically investigate the impact of real exchange rates on the growth of a large number of advanced and developing economies by employing non-stationary panel data estimation procedures to estimate conventional growth models augmented with global financial and monetary condition variables. The results show that the depreciation of the real exchange rate is contractive for developing economies with high external debt, but is expansionary for developed economies. Utilizing the generalized method of moment (GMM) dynamic panel data estimator for 83 countries spanning from 1960 to 2000; Aghion, Bacchetta, Ranciere, and Rogoff (2006) offer empirical evidence that real exchange rate volatility can have a significant impact on the long-term rate of productivity growth, but the effect depends critically on a country's level of financial development. The result shows that, for countries with relatively low levels of financial development, exchange rate volatility generally reduces growth, whereas for financially advanced countries there is no significant effect.

Hausmann, Pritchett and Rodrik (2004) study growth performance by looking for rapid acceleration in economic growth that lasts at least eight years. Using a dataset of 110 countries/regions from 1957 to 1992, the results of the study show that the acceleration of growth is often related to the depreciation of the real exchange rate. Also, Schnabl (2007) investigates the impact of exchange rate volatility on growth for a sample of 41 countries at the European Monetary Union periphery from 1994 to 2005 . Using the generalized least squares and generalized method of moment estimation techniques, the panel estimations for the overall sample reveal a significant negative impact of exchange rate volatility on growth. Di Nino, Eichengreen and Sbracia (2011) provide evidence of a positive correlation between undervaluation and economic growth in a panel data set spanning the period 1861 to 2011. Their results indicate that undervaluation will have a 
positive impact on growth by increasing the total value of exports. Vieira, Holland, Gomes Da Silva, and Bottecchia (2013) used a panel data set (1970 to 2009) to evaluate the effect of real exchange rate fluctuations in 82 advanced and emerging economies on long-term economic growth. By accurately measuring exchange rate volatility, the results of the two-step generalized moment panel (GMM) panel growth model show that a larger (less) volatile RER has a significant negative (positive) impact on economic growth.

Pablo Alfredo, Eduardo, and Federico (2012) estimate the impact of currency undervaluation on different components of GDP. The result suggests that for developing countries, undervaluation does not affect the tradable sector, but does lead to greater domestic savings and investment, as well as employment. On the other hand, Janus and Riera-Crichton (2015) study the impact of real effective exchange rate volatility on economic growth as well as the Euro's impact on effective real exchange rate volatility, using panel data for the period 1980 to 2011. The study shows that after a plausible endogeneity correction, real effective exchange rate volatility is negatively associated with growth in the Organization for Economic Cooperation and Development OECD countries. Therefore, this means that real effective exchange rate stability may promote growth in OECD countries. The empirical research of Gala (2008) provides new econometric evidence for the link between the real exchange rate level and development. Using panel data from the Generalized Method of Moments (GMM), the results of the study confirm that the undervaluation of the exchange rate is related to the increase in real per capita income.

Barguellil Ben-Salha and Zmami (2018) studied the impact of exchange rate fluctuations on economic growth. The empirical investigation is based on a sample of 45 developing and emerging countries over the period of 1985 to 2015. Using the system generalized moment estimator method, the research results show that the measurement of nominal and real exchange rate volatility based on generalized autoregressive conditional heteroscedasticity has a negative impact on economic growth. Whereas, Njindan Iyke (2018) studies the role of real currency misalignment in productivity growth for 100 middle-income countries for the period 1994 to 2010, using fixed-effects and generalized method of moment estimation techniques. The results show that if currency misalignment occurs as an undervaluation, it will increase productivity growth, but if it occurs as an overvaluation, it will hinder productivity growth. The research results also show that the impact of real currency misalignment on productivity growth is symmetrical. Nouira and Sekkat (2012) investigate the relationship between undervaluation and growth for 52 developing countries from Africa, Asia and Latin America using a panel data set from 1980 to 2005. The study employs OLS, GMM and panel co-integration. The result did not find any support for the claim that a depreciated real exchange rate promotes economic growth.

In general, the relationship between exchange rate changes and economic growth remains a difficult problem. Various studies done by other researchers have shown mixed effects, negative effects, positive effects and insignificant effects. A critical study on the main difference in the literature revealed that most of the conclusions were influenced by the kind of data used in the empirical analysis, the estimation technique or methodology, the geographical region or the country in which the study is conducted and the proxy for volatility. It is also found that very few studies seem to focus on WAMZ countries, which have studied the impact of exchange rate fluctuations on economic growth. These studies are mainly carried out within the framework of a single country, using time series data and using cointegration techniques. Therefore, the need to use panel data about WAMZ economies to conduct further research on the impact of exchange rate fluctuations on economic growth cannot be overemphasized. Thus, in this regard the trust of this study was developed in order to overcome the shortcomings and limitations of previous studies.

\section{3: Model Specification, Definition of the Variables, the Scope and Source of Data, Measurement of exchange rate volatility, and Methodology}




\section{The Model Specification}

In order to study the impact of exchange rate fluctuations on the economic growth of WAMZ countries, I used the traditional growth model, which is the panel data version of Umaru et al. (2018), with some modifications. The control variables were selected based on conventional theory, and following Karadam (2014). The model is based on the following assumption: Except for the variables included in the model, other variables remain unchanged. This model explores a linear relation between economic growth and other explanatory variables as follows:

$G D P=f(X, M, T B, I N F, N E R, R E R, V O L)$

In log linear form, the model of the research with the dependent and independent variables is given as:

$L n G D P_{i t}=\alpha_{0}+\alpha_{1} L n X_{i t}+\alpha_{2} L_{n M} M_{i t}+\alpha_{3} T B_{i t}+\alpha_{4} I N F_{i t}+\alpha_{5} L n N E R_{i t}+\alpha_{6} L n R E R_{i t}+\alpha_{7} L n V O L_{i t}+U_{i t}$

The natural logarithm is used in some variables to reduce the incidence of heteroscedasticity, and also, to allow the interpretation of the results in terms of elasticities. That is the response of the dependent variable, which can be explained by a $1 \%$ increase in the independent variable.

\section{Definition of the variables and expected signs}

The subscript i represents the cross-sectional dimension, $t$ denotes the time-series dimension, $U$ is an error term, $\mathrm{LnX}$ is the $\log$ of the total value of exports, $\mathrm{LnM}$ is the $\log$ of the total value of imports, TB is the trade balance, LnGDP is the log of the gross domestic product, LnRER Is the logarithm of the real exchange rate, measured by $\left\{\right.$ nominal exchange rate $(\mathrm{NER}) *$ foreign commodity price $\left(\mathrm{P}_{\mathrm{f}}\right) /$ domestic commodity price $\left(\mathrm{P}_{\mathrm{d}}\right)$ \}, INF is the inflation rate and LnVOL is the exchange rate volatility proxy generated from the monthly real effective exchange rates. In this paper, the nominal exchange rate is the relative price of local currency units divided by the relative price of the U.S. dollar (RPLCU/RPUSD). In addition, an increase in the exchange rate in this paper indicates a depreciation of the domestic currency, while a decline indicates an appreciation of the domestic currency.

LnGDP is the dependent variable of the equation (3). As far as the expected signs of these estimated coefficients are concerned, in this equation, $\alpha_{0}$ is the constant intercept. When a country exports goods, it sells them to a foreign market, that is, to consumers, businesses, or governments in another country. Those exports bring money into the country, which increases the exporting nation's GDP, so that $\alpha_{1}>0$. Alternatively, when a country imports goods, it buys them from foreign producers. The money spent on imports leaves the economy, and that decreases the importing nation's GDP, so that $\alpha_{2}<0$. If domestic consumers spend more on foreign products than domestic producers sell to foreign consumers, this will result in a trade deficit, hence, GDP decreases, thus $\alpha_{3}<0$. High inflation in the domestic economy means that the prices of goods produced in that economy increase quicker than foreign goods. Hence, domestic goods become less competitive. Demand for domestic exports will fall, and therefore, it implies less income for the economy, which reduces the GDP, so that $\alpha_{4}<0$. An increase or depreciation in the nominal exchange rate (LnNER), a priori, will make exports more competitive than before, thereby increasing the demand for domestic exports, this has a positive influence on the income and hence on GDP, so that $\alpha_{5}>0$. Similarly, the sign of the real exchange rate (LnRER) is expected to be positively related to the GDP, so that $\alpha_{6}>0$. And the sign of the exchange rate volatility (LnVOL) is indeterminate.

\section{The Scope and Data Sources}


As mentioned earlier, Figures 1 and 2 show that the country under consideration experienced significant exchange rate and GDP fluctuations from 1992 to 2017 respectively. Hence, the study employs annual data from 1992 to 2017 to capture the period in the analysis. For variables, units of measurement and their sources, see Table 1 below.

Table 1: Variable, Unit of Measurement and Sources

\begin{tabular}{|c|c|c|c|}
\hline NO. & Variables & Unit of Measurement & Source \\
\hline 1 & $\begin{array}{l}\text { Nominal exchange rate } \\
\text { (NER) }\end{array}$ & $\begin{array}{l}\text { The Relative price of the Local } \\
\text { currency unit divided by the } \\
\text { relative price of the US dollar } \\
\text { (RPLCU/RPUSD). }\end{array}$ & World Bank \\
\hline 2 & Real exchange rate (RER) & Current US dollars & $\begin{array}{l}\text { Author's Calculation }\left(\mathrm{NER} * \mathrm{P}_{\mathrm{f}} / \mathrm{P}_{\mathrm{d}}\right) \\
\mathrm{P}_{\mathrm{f}}=\text { foreign price level (proxy as } \\
\mathrm{USCPI} \text { ) } \\
\mathrm{P}_{\mathrm{d}}=\text { domestic price level (proxy as } \\
\text { domestic } \mathrm{CPI} \text { ) }\end{array}$ \\
\hline 3 & $\begin{array}{lll}\text { The United } & \text { States } \\
\text { Consumer Price } & \text { Index } \\
\text { (USCPI) } & & \\
\end{array}$ & Current US dollars & World Bank \\
\hline 4 & $\begin{array}{l}\text { Consumer price index } \\
(\mathrm{CPI}) \text { for the domestic } \\
\text { economies/countries. }\end{array}$ & Current dollar & World Bank \\
\hline 5 & $\begin{array}{l}\text { Exports of goods and } \\
\text { services }(\mathrm{X})\end{array}$ & Current US dollars & World bank \\
\hline 6 & $\begin{array}{l}\text { Imports of goods and } \\
\text { services }(\mathrm{M})\end{array}$ & Current US dollars & World bank \\
\hline 7 & $\begin{array}{ll}\text { Gross } & \text { domestic } \\
\text { product(GDP) } & \end{array}$ & Current US dollars (billions) & World bank \\
\hline $\begin{array}{l}9 \\
10\end{array}$ & $\begin{array}{l}\text { Trade balance (TB) } \\
\text { Inflation rates (INF) } \\
\text { Exchange Rate Volatility } \\
\text { (VOL) }\end{array}$ & $\begin{array}{l}\text { Current US dollars (billions) } \\
\text { GDP, deflator (annual \%) } \\
\text { Annual variation by averaging the } \\
\text { variance of twelve months of } \\
\text { each year. }\end{array}$ & $\begin{array}{l}\text { Author's Calculations (Exports - } \\
\text { Imports) } \\
\text { World bank } \\
\text { Author's calculation using STATA } \\
13 \\
\text { (Estimations were based on the } \\
\text { monthly real effective exchange rate } \\
\text { data, and obtained from the } \\
\text { bruegel.org/publication/ dataset). }\end{array}$ \\
\hline
\end{tabular}

Source: Adopted from (Fofanah 2020b).

\section{Measurement of exchange rate volatility}

In the discussions of the measures of exchange rate volatility, it is important to note the issues that are relevant for WAMZ countries under consideration. Note that during the period of estimation (from 1992 to 2017), the exchange rate arrangement of each of the countries varied from time to time. For example, in the WAMZ countries, a fixed exchange rate was implemented before the structural adjustment program was 
implemented, which allowed these countries to liberalize their economies and exchange rates, and later implemented devaluation policies. However, it must be pointed out that the devaluation policy adopted by the WAMZ countries under consideration does not necessarily reduce exchange rate fluctuations.

It is obvious from the review of the literature that one of the major issues in estimating the effect of exchange rate volatility on economic growth is choosing an appropriate proxy to represent the exchange rate volatility. The question of the appropriate proxy of exchange rate volatility is one that is unresolved among researchers (see Chit 2008; and Clark et al. 2004). Few researchers support that the use of either nominal or real rates would not make much difference (see Huchet-Bourdon \& Korinek, 2011). Also, Clark et al. (2004) provided evidence that there is no difference in using nominal or real exchange rate as a proxy and conclude that even though the nominal and real exchange rates are conceptually distinct, they tend to move closer together due to the stickiness of domestic prices.

A variety of proxies have been employed to represent exchange rate volatility in the previous empirical studies and there is no consensus on the appropriate proxy. Consequently, some studies use different proxies for exchange rate volatility to test their models (for example, Chit, 2008; Dell'arrida, 1999; and Clark et al. 2004). Since this paper is interested in establishing the effects of exchange rate volatility on economic growth, I use the real effective exchange rate in this study. The real effective exchange rate REER is the weighted average of a country's currency in relation to an index or basket of other major currencies. Countries with the largest trading relationships would typically have the largest weightings in this comparative index, while countries with small trading relationships would have smaller weightings in the basket of currencies. The weights are determined by comparing the relative trade balance of a country's currency against each country within the index. REER is used to evaluate how a currency is fluctuating against many others at once.

The other problem is the use of different measures of exchange rate fluctuations themselves. In general, there is no consensus on the most appropriate measure of exchange rate fluctuations. However, the key role of exchange rate volatility measurement is due to the fact that GDP depends critically on exchange rate changes. Thus, most studies have employed some sort of a measure of variance in their analysis to reflect the risks and uncertainty associated with the fluctuations in the exchange rate (see Chit 2008). Some studies use the standard deviation of the moving average of the logarithm of the real exchange rate. Other typical measures include the moving standard deviation of the percentage change in the exchange rate, the standard deviation of the first difference of the logarithm of real exchange rate, the moving average standard deviation of the logarithm of quarterly bilateral real exchange rate, and the conditional volatilities of real exchange rate estimated using autoregressive conditional heteroskedasticity $(\mathrm{ARCH})$ models, and their generalization, the generalized autoregressive conditional heteroskedasticity $(\mathrm{GARCH})$ models (see Chit 2008). Note that the use of the standard deviation as a measure of volatility may not be reliable because of the assumption that the data series should follow a normal distribution pattern. This is because the series might be skewed and exhibits a property known as kurtosis. In addition, a problem known as heteroskedasticity is also a serious concern. Heteroskedasticity simply means that the variance of the data series is not constant over time. In order to solve this problem, this study employs the robust standard error estimate of xtreg, cluster ( ) fe. This estimate is robust for the interference of heteroscedasticity and autocorrelation (see Torres-Reyna 2007). Hence, the paper employs an annual volatility measure of variance, which is obtained by averaging the variance of the real effective exchange rate for twelve months each year.

\section{Methodology of the Study}

This paper investigates the extent to which exchange rate volatility affects economic growth in WAMZ countries. The study employs similar econometric approaches of panel data analysis by Umaru et al. (2018); 
and Fofanah (2020b) because these models combine cross-sectional or time series data. Hsiao and Yanan (2006) identify several advantages of panel data analysis over cross-section or time-series analysis (see Fofanah 2020b, for the advantages). Despite the advantages of panel data analysis, the longer time dimension of panel data may lead to the problem of non stationarity and spurious regression, which deserves attention. Therefore, in order to conduct the initial test of non-stationarity, this study adopted the ImPesaran-Shin (2003) panel unit root test and Levin-Lin-Chu (2002) econometric test. These tests confirm whether the variables remain stable at a certain level to avoid biased results. The next stage is the estimation of the panel models using the following methodology: the pooled Ordinary Least Square (OLS), the fixed effects, and the random effects model.

Pooled Ordinary Least Square Model: This model assumes that any latent heterogeneity has been averaged out. The model is represented as follows: $Y_{t}=\beta_{0}+\beta_{1} X_{1 i t}+\beta_{2} X_{2 i t}+\ldots . .+C_{i}+U_{i t}$. Where $Y_{t}$ is the dependent variable, $U_{i t}$ is uncorrelated with all independent variables in $X, C_{i}$ is unobserved and it is absorbed into the error term (Fofanah 2020b). Thus we can rewrite the above model as: $Y_{t}=\beta_{0}+\beta_{1} X_{1 i t}+$ $\beta_{2} X_{2 i t}+\ldots . .+V_{i t}$. Where $V_{i t}=C_{i}+U_{i t}$ The error term $V_{i t}$ consists of two components, an "idiosyncratic" $U_{\text {it }}$ component and an "unobserved heterogeneity" $C_{i}$ component (McManus 2011). The question now, is what can be expected of the estimator when the heterogeneity does differ across countries or individuals? The fixed parameters, referred to as fixed effects model, can provide a way to deal with the bias and inconsistent estimates.

The Fixed Effect Model (FE): This model can handle heterogeneous effects.. The model can allow the unobserved individual and/or time-specific effects to be correlated with the independent or included variables but does not allow the estimation of the time-invariant coefficients (Fofanah 2020b). The functional form of the one-way fixed-effect model is: $Y_{t}=\left(\beta_{0}+C_{i}\right)+\beta_{1} X_{1 i t}+\beta_{2} X_{2 i t}+\ldots+U_{i t}$. Assume that $\mathrm{C}_{\mathrm{i}}$ is constant; this model is usually referred to as the least squares dummy variable (LSDV) model. The "least squares" part of the name referred to the technique usually used to estimate it, and not the model itself. The LSDV model, however, becomes problematic when there are many individuals (or groups) in panel data. In this situation, the number of parameters to estimate will increase. Therefore, the LSDV model is invalid due to the incidental parameters (Fofanah 2020b). This calls for another strategy, the random effect model which relies on the variations within each individual or entity.

Random Effect Model: The random effects assume that unobserved individual effects are strictly uncorrelated with the regressors, and then model the individual specific constant term as randomly distributed across cross-sectional units. The rationale behind the random-effects model is that, unlike the fixed effects model, the variation across entities is random and unrelated to the independent variables included in the model (Torres-Reyna, 2007). One of the advantages of the random effects model is that it can contain time-invariant variables. The model is: $Y_{t}=\beta_{0}+\beta_{1} X_{1 i t}+\beta_{2} X_{2 i t}+\ldots . .+C_{i}+U_{i t}$. In the randomeffects model, you need to specify those individual characteristics that may or may not influence the predictor variables Fofanah (2020b). The problem with this model is that some variables may be unavailable, which leads to missing variables in the model (Torres-Reyna, 2007). Feasible generalized least squares (FGLS) method is used to estimate the within-cluster correlation.

In addition, this paper uses the F-test, to determine between the pool OLS and the fixed effects models. The null hypothesis of the test is the pool OLS model, and the alternative hypothesis is the FE model. This actually tests the existence of fixed effects. The Bruesch and Pagan Lagrange Multiplier (BP-LM) test to decide between a random-effects regression model and a pool OLS regression model. The null hypothesis in the (BP-LM) test is that the variation across entities is zero. And Hausman test to determine whether it is pool OLS or fixed effects; the null hypothesis is that the preferred model is the pool OLS rather than fixed effect (Torres-Reyna, 2007). In order to ensure that the model does not have heteroscedasticity and serial correlation, I also conducted autocorrelation, heteroscedasticity and cross-sectional correlation tests. 
4. Results Presentation and Interpretation

Table 2: Descriptive Summary Statistics of the Variables

\begin{tabular}{|c|c|c|c|c|c|}
\hline Variable & \multicolumn{2}{|c|}{ ObsMean } & \multicolumn{2}{|c|}{ Std. Dev. } & $\operatorname{Max}$ \\
\hline RER & 104 & 1010.87 & 1662.89 & 1.00 & 4722.28 \\
\hline$X$ & 104 & 1.37 & 2.78 & 8.55 & 1.45 \\
\hline M & 104 & 1.09 & 1.85 & 1.28 & 8.89 \\
\hline GDP & 104 & 6.18 & 1.29 & 4.87 & 5.68 \\
\hline NER & 104 & 750.56 & 1512.39 & 0.04 & 7384.43 \\
\hline INF & 104 & 14.71 & 14.81 & ]-35.84 & 72.84 \\
\hline TB & 104 & 2.79 & 1.20 & -9.25 & 8.53 \\
\hline VOL & 104 & 2908.68 & 22253.83 & 0.97 & 224118.5 \\
\hline
\end{tabular}

Source: Author's computation using STATA 13

Table 2 above provides the summary descriptive statistics for the variables with a sample of 104 observations for each. The mean of the RER is 1010.87, the standard deviation SD is 1662.89 , the minimum and maximum values are 1.00 and 4722.28 respectively. In the case of exports (X) variable, the mean is 1.37 , the SD is 2.78 , the minimum and maximum values are 8.55 and 1.45 respectively. The imports (M) variable shows an average value of 1.09 , the SD is 1.85 , the minimum and maximum values are 1.28 and 8.89 respectively. The mean of the gross domestic product, GDP is 6.18 , the SD is 1.29 , minimum and maximum values are 4.87 and 5.68 respectively. The nominal exchange rate NER shows that the mean is $750.56, \mathrm{SD}$ is 1512.39 , the minimum and maximum values are 0.04 and 7384.43 respectively. Inflation rate, INF suggests that the mean is $14.71, \mathrm{SD}$ is 14.81 , the minimum and maximum values are -35.84 and 72.84 respectively. The trade balance TB indicates that the mean is $2.79, \mathrm{SD}$ is 1.20 , the minimum and maximum values are -9.25 and 8.53 respectively. And the real effective exchange rate volatility variable VOL shows that the mean value is 2908.68 , SD is 22253.83, the minimum and maximum values are 0.97 and 224118.5 respectively. See tables 3 and 4 below for a summary result of the unit root test:

Table 3: Im-Pesaran-Shin (2003) Panel Unit Root Test Result

\begin{tabular}{|c|c|c|c|c|c|c|}
\hline \multirow[t]{2}{*}{ Variables } & \multirow[b]{2}{*}{ t-bar } & \multicolumn{2}{|c|}{ Level } & \multicolumn{3}{|c|}{ First Difference } \\
\hline & & t-tilde-bar & Z-t-tilde-bar & t-bar & t-tilde-bar & Z-t-tilde-bar \\
\hline$\overline{\text { LnRER }}$ & -2.67 & -2.36 & $-2.39(0.00) * * *$ & & & \\
\hline $\operatorname{Ln} X$ & -1.56 & -1.511 & $-0.22(0.41)$ & -5.65 & -3.68 & $-5.78(0.00) * * *$ \\
\hline $\mathrm{LnM}$ & -1.97 & -1.83 & $-1.04(0.15)$ & -5.28 & -3.57 & $-5.51(0.00) * * *$ \\
\hline LnGDP & -1.31 & -1.25 & $0.45(0.67)$ & -4.95 & -3.41 & $-5.09(0.00) * * *$ \\
\hline LnNER & -2.35 & -2.15 & $-1.85(0.03) * *$ & & & \\
\hline INF & -3.36 & -2.67 & $-3.18(0.00) * * *$ & & & \\
\hline TB & -2.94 & -2.55 & $-2.88(0.00) * * *$ & & & \\
\hline LnVOL & -3.27 & -2.74 & $-3.37(0.00) * * *$ & & & \\
\hline
\end{tabular}

Note: $* * *$ and $* *$ represents the stationarity of the $1 \%$ and $5 \%$ significance levels, respectively. Values in the parentheses are P-value. The null hypothesis of the Im-Pesaran-Shin test with demean option is that "all panels contain unit roots". The results reject the null hypothesis for five of the series. This implies the integration of order zero I (0), for five variables, and integration of order one I (1), for three variables.

Table 4: Levin-Lin-Chu Unit-Root Test

\begin{tabular}{|lcc|}
\hline Variables & Levin-Lin-Chu Unit-Root Test-Statistics \\
\hline & Level & First Difference \\
\hline
\end{tabular}




\begin{tabular}{|lll|}
\hline LnRER & $-3.01(0.00) * * *$ & \\
\hline LnX & $-1.02(0.15)$ & $-2.78(0.00) * * *$ \\
\hline LnM & $-2.25(0.01)^{* *}$ & \\
\hline LnGDP & $-2.29(0.01) * *$ \\
\hline LnNER & $-2.03(0.02) * *$ \\
\hline INF & $-2.69(0.00) * * *$ & \\
\hline TB & $-0.38(0.35)$ & $-2.07(0.02) * *$ \\
\hline LnVOL & $-2.33(0.01) * * *$ & \\
\hline
\end{tabular}

Note: $* * *$ and $* *$ represents the stationarity of the $1 \%$ and $5 \%$ significance levels, respectively. Values in the parentheses are P-value. The null hypothesis of the Levin-Lin-Chu unit-root test is that "all panels contain unit roots". The results of the Levin-Lin-Chu panel unit root test in table 4, show that six of the series are stationary at level. While two are stationary at the first difference. Considering the two tests, since the majority of the results favor I (0), this study, therefore, considers that the variables under study are all I (0). With this conclusion, the next step will be to estimate the regression equation and select the most appropriate model for the study. The estimate of the pooled, fixed, and random effect models for the economic growth model is as follows. Tables 5a, b, c, and d present the results of the econometric tests, helping to decide on the best model for the study.

Table 5a: Output of OLS, FE, and RE Models

\begin{tabular}{|lccc|}
\hline Variable & Pooled OLS & Fixed Effect Model (FE) & Random Effect Model (RE) \\
\hline LnX & $0.82^{* * *}$ & $0.27^{* *}$ & $0.82^{* * *}$ \\
\hline LnM & $(0.09)$ & $(0.10)$ & $(0.09)$ \\
\hline & $0.22^{* *}$ & $0.50^{* * *}$ & $0.22^{* *}$ \\
\hline TB & $(0.10)$ & $(0.11)$ & $(0.10)$ \\
\hline & -2.34 & 1.00 & -2.34 \\
\hline INF & $(3.29)$ & $(2.69)$ & $(3.29)$ \\
\hline & -0.004 & -0.003 & -0.004 \\
\hline LnNER & $(0.00)$ & $(0.00)$ & $(0.00)$ \\
\hline & -0.06 & $0.16^{* * *}$ & -0.06 \\
\hline LnRER & $(0.05)$ & $(0.06)$ & $(0.05)$ \\
\hline & $0.13 * *$ & $-0.28^{* *}$ & $0.13 * *$ \\
\hline LnVOL & $(0.05)$ & $(0.11)$ & $0.05)$ \\
\hline & 0.02 & 0.02 & 0.02 \\
\hline Constant & $(0.02)$ & $(0.01)$ & 0.36 \\
\hline & 0.36 & $6.84^{* * *}$ & $(0.46)$ \\
\hline No. & $(0.46)$ & $(1.33)$ & 104 \\
\hline $\mathrm{r}^{2}$ & 104 & 104 & 0.89 \\
\hline Note: Stan & 0.98 & 0.92 & $p<0.05 *$ \\
\hline
\end{tabular}

Note: Standard errors in parenthesis; Statistical significance: $* * * \mathrm{p}<0.01 ; * * \mathrm{p}<0.05$.

Table 5b: Summary of F-Test Results in Choosing between OLS, and FE Models

\begin{tabular}{llllll}
\hline Model & F-Statistics & Degrees of & Probability & Decision & Decision \\
& Value & Freedom & & & \\
\end{tabular}

(DF) 


\begin{tabular}{|c|c|c|c|c|c|}
\hline $\begin{array}{l}\text { Economic } \\
\text { growth }\end{array}$ & 21.07 & $(3,93))$ & 0.0000 & Ho-rejected & $\begin{array}{l}\text { Pooled model } \\
\text { is } \\
\text { appropriate } \\
\text {--Fixed effects } \\
\text { model must be } \\
\text { estimated. }\end{array}$ \\
\hline
\end{tabular}

Note: The null hypothesis is that all dummy parameters except for one of the dropped are all zeros. The alternative hypothesis is that at least one dummy parameter is not zero. This hypothesis is tested by an Ftest.

Table 5c: Summary of Breusch and Pagan Lagrange Multiplier (BP-LM) Test for Random Effects

\begin{tabular}{|l|l|l|l|l|}
\hline Model & $\begin{array}{l}\text { Chi-Square } \\
\text { Statistics }\end{array}$ & Probability & Decision & Decision \\
\hline $\begin{array}{l}\text { Economic } \\
\text { growth }\end{array}$ & 0.00 & 1.0000 & Ho: rejected & $\begin{array}{l}\text { Random effect } \\
\text { model is not } \\
\text { appropriate }\end{array}$ \\
& & $\begin{array}{l}\text {----Pool model } \\
\text { must be } \\
\text { estimated. }\end{array}$ \\
\hline
\end{tabular}

Note: The Breusch and Pagan's Lagrange multiplier (LM) test checks whether individual (or time) specific variance components are zero. If the null hypothesis is not rejected, the pooled OLS is preferred; otherwise, the random effect model is better. Thus, from the output, there is, no evidence of significant differences across countries, therefore, I can run a pool OLS regression model.

Table 5d: Summary of the Hausman Test Result in Choosing the Appropriate Model

\begin{tabular}{|l|l|l|l|l|l|}
\hline Model & $\begin{array}{l}\text { Chi-Square } \\
\text { Statistics }\end{array}$ & Probability & & Decision & Decision \\
\hline $\begin{array}{l}\text { Economic } \\
\text { growth }\end{array}$ & 162.85 & 0.0000 & & Ho: rejected & $\begin{array}{l}\text { Fixed effects } \\
\text { model is the } \\
\text { appropriate } \\
\text { model }\end{array}$ \\
\hline
\end{tabular}

Note: To choose between fixed effects or pooled OLS, I ran the Hausman test, where the null hypothesis is that the preferred model is the pooled OLS model and the alternative is the fixed effects. Hence, after conducting the econometric tests (F-test, BP-LM test and Hausman test) to determine the appropriate model for this paper, the fixed effects appear to be the suitable model to explain the relationship between the dependent and the independent variables (see table 5a).

\begin{tabular}{|cccc|}
\hline \multicolumn{2}{|c|}{ Table 6: } & Results of Heteroskedasticity, Autocorrelation, & and Cross-Sectional Dependence Tests \\
\hline Model & Heteroskedasticity & Autocorrelation & Cross-Sectional \\
Dependence & & \\
\hline \hline
\end{tabular}
dep.)

(Ho:homoskedasticity) (Ho: no autocorrelation)

(H0: cross-sectional

\begin{tabular}{|cccc|}
\hline GDP model $(\mathrm{FE})$ & LR chi2 $(4)=16.17$ & $\mathrm{~F}(1,3)=62.675$ & PSI $=-0.522$ \\
\hline & Prob $>\mathrm{chi}^{2}=0.0028$ & Prob $>\mathrm{F}=\quad 0.0042$ & Prob $=0.6015$ \\
\hline
\end{tabular}


From table 6, the standard errors of the model have heteroskedasticity and serial correlation. However, there is no cross-sectional dependence as is shown by Pesaran's test of cross sectional independence. TorresReyna (2007) proved that the standard error estimate of xtreg, cluster()fe is robust to heteroscedasticity and autocorrelation interference. Therefore, to ensure the validity of the results, I obtained robust estimates by using xtreg, cluster ( ) fe. The result is shown in table 7 below.

Table 7: Robust Estimation Result

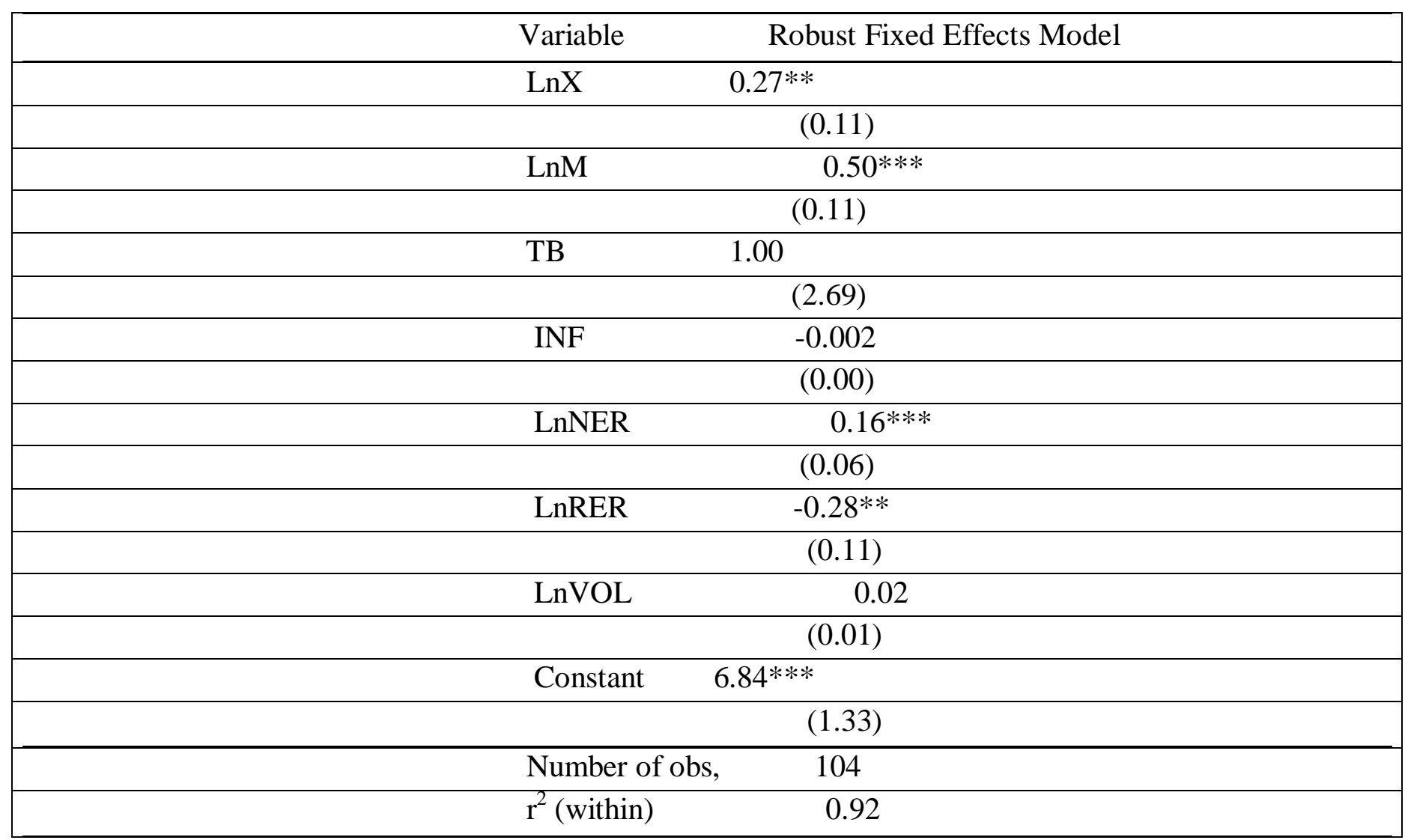

Note: Standard errors in parentheses; Statistical significance: $* * * p<0.01 ; * * p<0.05$.

The within $r^{2}$ of 0.92 says that this model accounts for 92 percent of the total variance in the GDP. The robust regression equation is:

$L n G D P_{i t}=6.84 * * *+0.27 * * \operatorname{LnX} X_{i t}+0.50 * * * \operatorname{LnM}_{i t}+1.00 T B_{i t}-0.002 I N F_{i t}+0.16 * * * \operatorname{LnNER}_{i t}-0$. $28 * * \operatorname{LnRER}_{i t}+0.02 \mathrm{LnVOL}$

From the robust regression equation in (4), the coefficients of $\mathrm{LnX}$, LnM, LnNER, and LnRER are statistically significant, at 5\%,1\%,1\%, and 5\% respectively. The expected sign of the LnX coefficient is consistent with the theoretical expectation. For a $1 \%$ increase in exports, gross domestic product is expected to increase by $27 \%$, holding all other variables constant. This finding is consistent with the findings of Syzdykova et al. (2019), although their analysis was carried out in Kazakhstan. On the other hand, for a $1 \%$ increase in imports, gross domestic product is expected to increase by $50 \%$, holding all other variables constant. This result is inconsistent with theoretical expectation, but however, consistent with the results of Kim et al. (2007); Mishra (2012); and Syzdykova et al. (2019) though their analysis is carried out for Asian countries. This result is not surprising for the countries under investigation. This is because the industrial and service sectors which also contribute to the GDP of the countries under consideration strongly rely on imported goods and services for their growth and survival. Furthermore, the beneficial impact of imports stems not only from the competitive pressures arising from imports of consumer goods, and expertise services, but also from technological transfers embodied in imports of capital/producer goods from developed countries. Hence, more imports imply more production of goods and services and hence, more growth in the GDP of WAMZ countries. 
The empirical results also show that a $1 \%$ depreciation in the nominal exchange rate or an increase in the nominal exchange rate will increase GDP growth rate by $16 \%$, holding all other variables constant. This result is consistent with the theory, and it conforms to the findings of Kogid et al. (2012), although their analysis was conducted in Malaysia. The empirical analysis further suggests that a $1 \%$ depreciation in the real exchange rate or an increase in the real exchange rate will decrease GDP growth rate by $28 \%$, holding all other variables constant. This result is inconsistent with the theory, but however, conforms to the findings of Ghura and Grennes (1993); and Umaru et al. (2018). In addition, the results further show that whenever trade balance increase by $1 \%$, GDP growth rate will increase by $100 \%$ and correspondingly, an increase in inflation rate by $1 \%$, will decrease GDP growth rate by $0.2 \%$, holding all other variables constant. However, these variables are insignificant in determining GDP growth rate in the countries under consideration. The exchange rate volatility, which is the main variable of interest suggests that if the exchange rate volatility increases by $1 \%$, the GDP growth rate will increase by $2 \%$, holding all other variables constant. This variable is however not significant in determining the GDP growth rate. This finding is consistent with the result of Anyanwu et al. (2017), even though they examined the real exchange rate and economic growth, but differ from the findings of Barguellil Ben-Salha and Zmami (2018), whose findings reveal a negative relationship between exchange rate volatility on the economic growth of developing and emerging countries. And also, differs from the result of Adeolu and Godwin (2013), whose findings produced more significant effects in the non-CFA group than in the CFA.

\section{5: Conclusion and Policy Recommendations}

This study examines the impact of exchange rate volatility on economic growth, focusing on four WAMZ countries. Taking exchange rate volatility as the main interest variable, the empirical results show that the impact of exchange rate volatility on economic growth is insignificant. Although the impact of exchange rate volatility on economic growth is insignificant, the results of the model also show that there is a positive and significant relationship between exports and economic growth. Therefore, with the increase in exports, the GDP growth rate tends to increase. This fact shows that a policy aimed at increasing exports through an appropriate exchange rate may be beneficial to WAMZ countries. In addition, the analysis shows a positive and significant link between imports and GDP growth rate. Implying that increase in imports will lead to an increase in GDP growth rate. This therefore confirms that WAMZ countries actually benefit from imports, which is derived from the competitive pressures arising from imports of consumer goods, as well as expertise, and also from technological transfers embodied in imports of producer goods. Hence, a policy of removing import barriers will tend to benefit WAMZ countries. Again, the results show that an increase in the nominal exchange rate will increase GDP growth rate. This result implies that tradables will become more competitive than before when the nominal exchange rate depreciates or increases, this thereby leads to increase in the demand for domestic tradables, this has a positive influence on the income and hence GDP growth rate of the countries under consideration. Therefore, it shows that the nominal exchange rate depreciation policy can play an important role in improving the GDP of WAMZ countries.

However, the findings further suggest that depreciation in the real exchange rate will decrease GDP growth rate. This means that WAMZ countries should be extra careful when implementing exchange rate depreciation policies, because it may harm the GDP growth rate. Thus, considering the importance of exchange rate variables, especially the real exchange rate, this finding suggests that a prudent exchange rate via monetary policy should be carefully developed and implemented to promote the stability and sustainability of economic growth in WAMZ countries. For future research, prospective researchers may consider using different measurements and proxies of exchange rate volatility to find out whether there would be differences in the outcome of the empirical analysis. 


\section{References}

[1] Abida, Zouheir. (2011). Real Exchange Rate Misalignment and Economic Growth: An Empirical Study for the Maghreb Countries. Zagreb International Review of Economics and Business, Faculty of Economics and Business, University of Zagreb , 14 (2), 87-105.

[2] Adeolu .O. Adewuyi \& Godwin Akpokodje. (2013). Exchange Rate Volatility and Economic Activities of Africa's Sub-Groups. The International Trade Journal , 27 (4), 349-384.

[3] Africa Development Bank. (2019). West Africa Economic outlook, macroeconomic performance and prospect. Regional and structural transformation in West Africa. internet source .

[4] Aghion,P., Bacchetta,P., Ranciere,R., and Rogoff,K. (2006). Exchange Rate Volatility and Productivity Growth: The Role of Financial Development. National Bureau of Economic Research, Working Paper (12117).

[5] Alexander, S.S. (1959). A simplified synthesis of elasticities and absorption approaches. American Economic Review , 49, 22-42.

[6] Alexander, S.S. (1952). Effects of devaluation on a trade balance. International Monetary Fund Staff Papers , 2, 263-78.

[7] Anyanwu, Felicia Akujinma \& Ananwude, Amalachukwu Chijindu \& Okoye, Ngozi Theodora. (2017). Exchange Rate Policy and Nigeria's Economic Growth: A Granger Causality Impact Assessment. International Journal of Applied Economics, Finance and Accounting , 1 (1), 1-13.

[8] Attah-Obeng, P., P.E. Osei-Gyimah,F and C.D.K. Opoku. (2013). An Econometric Analysis of the Relationship between GDP Growth Rate and Exchange Rate in Ghana. Journal of Economics and Sustainable Development , 4 (9).

[9] Bahmani-Oskooee, Mohsen and Abera Gelan. (2018). Exchange-rate volatility and international trade performance: Evidence from 12 African countries. Economic Analysis and Policy, 58, 14-21.

[10] Balima,H.W., Barhoumi,K., Gorbanyov,M., Versailles,B., and Towfighian,S.N. (2018). Growth Accleration in the West African Ecomomic and Monetary Unoin. International Monetary Fund IMF Country Report (18/107).

[11] Barguellil, A., Ben-Salha, O., \& Zmami, M. (2018). Exchange Rate Volatility and Economic Growth. Journal of Economic Integration, 33 (2), 1302-1336.

[12] Beck, T., Demirgüç-Kunt, A., Levine, R. (2009). Financial Institutions and Markets Across Countries and over Time: Data and Analysis. World Bank Policy Research Working Paper, 4943.

[13] Belk, A., and Gros, D. (2001). Real impact of Intra-European Exchange Rate Variability:A Case for European Monetary Union EMU? Open Economy Review, 12 (3), 231-264.

[14] Belke, A., and Setzer, R. (2003). Exchanhge Rate Volatility and Employment Growth: Empirical Evidence from the Central and Eastern Europe. CESifo working paper , 1056.

[15] Betten, D. S. \& Belongia, M.T. (1984). The recent decline in Agricultural Exports: Is the exchange rate the culprit? Federal Reserve Bank of St. Louis.

[16] Chang, S. (2011). The interrelationship between exchange-rate uncertainty and unemployment for South Korea and Taiwan: Evidence from a vector autoregressive approach. Economie internationale , 125 (1), 65-82.

[17] Chen, James. (2019). Overshooting. Investopedia, internet source.

[18] Chit, Myint Moe. (2008). Exchange rate volatility and exports: the case of emerging East Asian economies. PhD thesis, Middlesex University; Available online at google .com.

[19] Clark, P., Tamirisa, N., Wei, S. J., Sadikov, A. and Zeng, L. (2004). Exchange Rate Volatility and Trade Flows-Some New Evidence. International Monetary Fund. 
[20] Dell' 'Ariccia, G. (1999). Exchange Rate Fluctuations and Trade Flows: Evidence from the European Union. International Monetary Fund Staff Papers , 46 (3), 315-334.

[21] Dhakal,D., Nag,R., Pradhan,G., Kamal P. Upadhyaya. (2010). Exchange Rate Volatility And Foreign Direct Investment: Evidence From East Asian Countries. International Business \& Economics Research Journal , 9 (7).

[22] Dhakir Abbas Ali, Fuadah Johari, and Mohammad Haji Alias. (2014). The Effect of Exchange Rate Movements on Trade Balance:. Hindawi Publishing Corporation, ID 893170.

[23] Di Nino, Virginia \& Eichengreen, Barry and Sbracia, Massimo. (2011). Real Exchange Rates, Trade, and Growth. Economic History Working Paper, 10, ISSN2281-6097.

[24] Dornbusch, Rudiger. (1976). Expectations and Exchange Rate Dynamics. Journal of Political Economy , 84, 1161-1176.

[25] Driskill, Robert. (1981). Exchange rate overshooting, the trade balance, and rational expectations. Journal of International Economics , 11, 361 - 377.

[26] Edwards, S. (1989). Real Exchange Rate in Developing Countries: Concepts and Measurements. Working Paper, National Bureau of Economic Research (NBER) Massachusetts, Cambridge. , No. 2950.

[27] Eichengreen, B. (2008). The Real Exchange Rate and Economic Growth. Commission on Growth and Development Working Paper, World Bank, Washington, D.C. , No. 4.

[28] Fatum, R., Liu,R., Tong, J. and Xu, J. (2018). Beggar thy neighbor or beggar thy domestic firms? Evidence from 2000 to 2011 Chinese customs data. Journal of International Economics. , 115, 1629.

[29] Fleming, J. Marcus. (1962). Domestic Financial Policies under Fixed and under Floating Exchange Rates".International Monetary Fund Staff, 9, 369-379.

[30] Fofanah, P. (2020b). Effects of Exchange Rate Volatility on Trade: Evidence from West Africa. Journal of Economics and Behavioral Studies , 12 (3), 32-52.

[31] Fofanah, P. (2020a). Impact of Real Exchange Rate Fluctuations on Aggregate Cocoa and Coffee Exports in Sierra Leone. Journal of Economics and Behavioral Studies , 12 (2), 34-56.

[32] Frankel, J. A. (2005). Mundell-Fleming Lecture: Contractionary Currency Crashes in Developing Countries. IMF Staff Papers, 55 (2), 149-192.

[33] Gala, Paulo. (2008). Real exchange rate levels and economic development: theoretical analysis and econometric evidence. Cambridge Journal of Economics , 32, 273-288.

[34] Ghura, Dhaneshwar and Grennes, Thomas.J. (1993). The real exchange rate and macroeconomic performance in Sub-Saharan Africa. Journal of Development Economics , 42 (1), 155-174.

[35] Habib, M.M., Mileva, E. and Livio,S. (2016). The real exchange rate and economic growth: revisiting the case using external instruments. Working Paper, European Central Bank. , Series 1921.

[36] Hausmann, R., Pritchett, L., and Rodrik, D. (2004). Growth Accelerations. National Bureau of Economic Research (NBER), Working Paper, No. 10566.

[37] Hua, Ping. (2012). Real Exchange Rate and Economic Growth in China. Journal of Reviews on Global Economics , 1, 89-105.

[38] Im, K. S., M. H. Pesaran, and Shin, Y. (2003). Testing for unit roots in heterogeneous panels. Journal of Econometrics, 115, 53-74.

[39] Inam, Uduakobong .S., and Umobong, Enobong .C. (2015). An Empirical Analysis of the Relationship between Exchange Rate Movements and Economic Growth in Nigeria. European Journal of Business and Management, 7 (30), ISSN: 2222-1905. 
[40] Janus, T. and Riera-Crichton, D. (2015). Real Exchange Rate Volatility, Economic Growth and the Euro. Journal of Economic Integration, 30 (1), 148-171.

[41] Javed, Zahoor Hussain and Farooq, Muhammad. (2009). Economic Growth and Exchange Rate Volatility in Case of Pakistan. Pakastan Journal of life and social sciences , 7 (2), 112-118.

[42] Jiang,Wunhui. (2014). The Effect of RMB Exchange Rate Volatility on Import and Export Trade in China. International Journal of Academic Research in Business and Social Sciences , 4 (1), ISSN 2222-6990.

[43] Jibrin,A.A., \& Jelilov, G., and Gayypov,Y. (2017). Exchange Rate and Economic Growth in Economic Community of West African States (ECOWAS). The Empirical Economics Letters , 16 (5), 519-529.

[44] Karadam, Duygu Y. (2014). Real Exchange Rate and Growth. PhD. Thesis, retrieve from the internet. http//google.com.

[45] Karadam,Duygu Y. and Ozmen, Erdal . (2016). Real Exchange Rate and Growth". Economic Research Centre, Working Paper in Economics, http//google.com. , 16/09.

[46] Kim, S., Lim, H., and Park, D. (2007). Could Imports be Beneficial for Economic Growth: Some Evidence from Republic of Korea. Asian Development Bank, Economic and Research Department, Working paper series, No.103.

[47] Kogid ,M., Asid,R., Lily,J., Dullah,D. and Loganathan,N. (2012). The Effect of Exchange Rates on Economic Growth: Empirical Testing on Nominal Versus Real. The IUP Journal of Financial Economics , 10 (1), No 42J.

[48] Koirala, Sujan. (2018). An Analysis of the Impact of Real Effective Exchange Rate on Economic Growth of Nepal. Pravaha Journal of Management, 24 (1), 206-216.

[49] Kristinek, J.J., and Anderson, D.P. (2002). Exchange rate and agriculture: A literature review. Agricultural and Food Policy Center (AFPC) Working Paper, No. 02-2.

[50] Levin, A., C.F. Lin, and C.S. J. Chu. (2002). Unit root tests in panel data: Asymptotic and finitesample properties. Journal of Econometrics , 108, 1-24.

[51] Levy-Yeyati, E., and Sturzenegger, F., and Gluzmann, P. A. (2013). Fear of appreciation. Journal of Development Economics Elsevier, 101, 233-247.

[52] Mamun, A., Chowdhury, A.H. and Basher,S. (2013). Effects of Exchange Rate Variation on Price Level and Output Growth in Bangladesh. Mediterranean Journal of Social Sciences , 4 (6).

[53] McManus, Patricia .A. (2011). Introduction to Regression Models for Panel Data Analysis. Indiana University, Workshop in Methods. Internet source, http://google.com.

[54] Meniago, C. and Eita, J.H. (2017). The effects of exchange rate changes on Sub-Saharan Africa trade. International Journal of Sustainable Economy, 9 (3), 213-230.

[55] Mishra, P. K. (2012). Dynamics of the relationship between imports and Economic growth in India. South Asian Journal of Macroeconomics and Public Finance, Internet source.

[56] Mundell, Robert A. (1963). Capital Mobility and Stabilization Policy under Fixed and Flexible Exchange Rates.Canadian Journal of Economics and Political Science , 29, 475-485.

[57] Ndambendia, Houdou and Alhayky, Ahmed. (2011). Effective Real Exchange Rate Volatility and Economic Growth in Sub-Saharan Africa: Evidence from Panel Unit Root and Cointegration Tests. The IUP Journal of Applied Finance, 17 (1), 85-94.

[58] Njindan Iyke, B. (2018). The real effect of currency misalignment on productivity growth: evidence from middle-income economies. Internet source, 55 (4), 1637-1659.

[59] Nouira,R., and Sekkat,K. (2012). Desperately seeking the positive impact of undervaluation on growth. Journal of Macroeconomics , 34, 537-552. 
[60] Oloyede, A.J., and Fapetu, O. (2018). Effect of exchange rate volatility on economic growth of Nigeria. Afro Asian Journal of Finance and Accounting , 8 (4), 404-412.

[61] Pablo Alfredo, Glüzmann \& Eduardo, Levy-Yeyati \& Federico, Sturzenegger. (2012). Exchange rateundervaluation and economic growth: Díaz Alejandro (1965) revisited. Economics Letters, Elsevier, 117 (3), 666-672.

[62] Pradhan, G., Z. Schuster, and K. Upadhyaya. (2004). Exchange Rate Uncertainty and the Level of Investment in Selected South-East Asian Countries. Applied Economics , 36, 2161-2165.

[63] Razzaque ,M.A., Bidisha,S.H., and Khondker,B.H. (2017). Exchange Rate and Economic Growth: An Empirical Assessment for Bangladesh. Journal of South Asia Development , 12 (1), 42-64.

[64] Rodrik, Dani. (2008). The Real Exchange Rate and Economic Growth. Brookings Papers on Economic Activity,39 (2), 365-439.

[65] Sani, I.A., Hassan, S., and Azam, M. (2016). Effects of Exchange Rate Volatility on Output in Some Selected West Africa Countries. International Journal of Development and Economic Sustainability, 4 (1), 1-10.

[66] Schnabl, Gunther. (2007). Exchangr Rate Volatility and Growth in Small Open Economies at the European Monetary Union Periphery. The European Central Bank Working Paper Series, http//google.com. , No.773.

[67] Serven, L. (2003). Real-Exchange Rate Uncertainty and Private Investment in LDCs. Review of Economics and Statistics , 85, 212-218.

[68] Sibanda, Kin \& Ncwadi, Rooney, and Mlambo, Courage. (2013). Investigating the Impacts of Real Exchange Rates on Economic Growth: A Case study of South Africa. Mediterranean Journal of Social Sciences , 4 (13), 2039-9340.

[69] Snape, R. H. (1988). Real exchange rate, real interest rate, and agriculture. Conference paper: Agriculture and government in an independent world. Proceedings of the Twentieth International Conference of Agricultural Economists. Internet source.

[70] Syzdykova A., Abubakirova A.,Kelesbayev D.,Omarova A.,Amaniyazova G., Saubetova B., Anshayeva D. (2019). The Effect of Export and Imports on National Income in Kazakhstan: Econometric Analysis. Revista ESPACIOS , 40 (35), 22.

[71] Tarawalie, A.B. (2010). Real exchange rate behaviour and economic growth: Evidence from Sierra Leone. South African Journal of Economic and Management Sciences., Pretoria , 13 (1), 8-25.

[72] Tarawalie,A.B., Sissoho,M., Conte,M., and Ahortor, C.R. (2012). Exchange Rate, Inflation and Macro Economic Performance in the West Africa Monetary Zone (WAMZ). WAMI Occasional papers. Retrieved via http//google.com. , No. 2.

[73] Torres-Reyna, Oscar. (2007). Panel Data Analysis Fixed and Random Effects using Stata. Obtained from http://google.com.

[74] Ullah, I., Khan, M.I., and Khan, Saif-ud-Din. (2017). Linkages between exchange rate and economic growth in Pakistan (an econometric approach). European Journal of Law Economics , 44 (1), 157 164.

[75] Umaru, H., Aguda, N.A., Davies, N.O. (2018). The Effects of Exchange Rate Volatility on Economic Growth of West African English-Speaking Countries. International Journal of Academic Research in Accounting, Finance and Management Sciences , 8 (4), 131-143.

[76] Vieira, F.V., Holland, M., Gomes da Silva, C. and Bottecchia, L.C. (2013). Growth and exchange rate volatility: a panel data analysis", Applied Economics. Taylor \& Francis Journals , 45 (26), 3733-3741.

[77] Vieira, Flávio Vilela, and MacDonald, Ronald. (2012). A Panel Data Investigation of Real Exchange Rate Misalignment and Growth. Estudios De Economia , 42 (3), 433-456. 
[78] Zagorsky, Jay, L. (2018). What is full employment? An economist explains the latest jobs data. Internet source. 